\title{
3 Summary of Sermones Book 1: Horace's Credentials Containing Political Commentary; Virgil's Eclogae and Horace's Sermones Book 1 Compared
}

\subsection{Introduction to the Chapter}

In this chapter I aim to bring together the results of my study of the individual sermones and draw some general conclusions related to the first book of Sermones as a whole. Although Horace's main purpose writing the book is his self-presentation, he also presents in S.1 commentary on some contemporary political issues. In this last chapter, I intend to sketch the nature of his self-presentation and his poetic choice, and also to determine the main issues of his political commentary that he intertwines through his representation. At first, I will present in section 3.2 summaries of the results of my analyses of the ten sermones.

Subsequently, I will discuss in section 3.3 my interpretation of the first book of Sermones as a collection of Horace's credentials for Maecenas and I will trace his efforts in getting accepted as an associate of the latter. S.1 contains a number of his reflections on his poetic orientation and of his views on standards of good poetry. I will consider those within the context of his self-presentation. Next, I will examine in section 3.3 the main political themes which he presents in the book. Further, I will give in this section a broad outline of his political commentaries in his other work of the period of 38 - 30 B.C., and I will compare those with that in S.1. Consequently, I will examine the commentary he presents in Sermones book 2, the Epodi and some of the Carmina of the same period. I will make use of some of the results of my thesis (Weeda, 2010), in which I analysed the political content of the complete extant oeuvre of Virgil, Horace and Propertius.

Finally in section 3.4, I will compare Virgil's Eclogae and Horace's Sermones book 1 with respect to the nature of political commentary in either book. Both poets were born during the civil war and experienced the transition and political change from the Republic to the early Principate, and both lived and worked as associates of Maecenas.

\subsection{Summary of Sermones Book 1}

Concerning $S .1$ as a whole, a clear distinction in two main matters of content is apparent. Firstly, Horace offers in $S .1 .1-S .1 .4$ and in $S .1 .10$ his credentials by presenting his views on his poetic orientation and his standards for good poetry, on socio-political contemporary issues and on behaviour among friends. He chose and presented the issues in such a way that he maximized the chance of finding favour with Maecenas at the same time getting Maecenas and his audience of the latter's

2 Open Access. () 2019 Leendert Weeda, published by Sciendo. (cc) BY-NC-ND This work is licensed under the Creative Commons Attribution-NonCommercial-NoDerivs 4.0 License. 
associates accustomed to his future role as political observer and commentator. Secondly, he describes in S.1.5 - S.1.9 both his personal "experiences" and efforts to achieve his association with Maecenas and his position after actually having achieved membership of the latter's circle. Many of the "events" and "experiences" described in S.1.5 - S.1.9 are poetic fiction with only a few autobiographical elements. In S.1.5 - S.1.9 Horace expresses his loyalty towards Maecenas and continues declaring his trustworthiness as an associate. S.1.10 stands apart as the poet is concerned with both matters of content. In S.1.10.1-77, he repeats his views on writing good poetry, while in the last passage (lines 78-92) he expresses his contentment with his newly found circle of colleagues and friends.

When one considers S.1.1 - S.1.9 from the point of structure of the poems, one notes that S.1.1 - S.1.4 are characterized by their focus on philosophical teachings and literary choices, written in a conversational mode of presentation. S.1.5 - S.1.9 is a series of anecdotes, apart from the first forty four lines of S.1.6. Horace narrates in S.1.5 a journey, in S.1.6.45-131 his "father's" efforts for his education, his years with Orbilius and his typical day in Rome, in S.1.7 an experience with Brutus in Asia, in S.1.8 the events on the Esquiline with the witches, and in S.1.9 his meeting with the pushy nouveau riche on the Via Sacra. S.1.10.1-77 has again a focus on literary teachings.

With respect to the detail of the content of S.1, I will review each sermo. In this review, I present only my conclusions; the supporting evidence is given in the discussions of the individual sermones in section 2.2.

Horace chose as subject for discussion in S.1.1 greed (avaritia), ambition (ambitio) and extravagance (luxuria), and shows his concern about the impact of the rejection of the old Roman values and the loss of moral standards by both common people and the new rich on the political stability in Rome and Italy. Immediately at the start of S.1, Horace recalls that the Stoic Fabius also recounted in his writings the conduct of different types of men. Horace achieves through the functional reference to Fabius two objectives. Firstly, the poet makes a statement about his style as a politically engaged poet: he intends to write in a sophisticated and subtle manner, as he will appeal to his readers' education and sophistication. Secondly, he confronts through Fabius a whole group of contemporary poets, Stoics, republicans and generally men of a very different political leaning than his own; men, with whom he does not wish to be associated. Horace states not only that his style will not be as bombastic and unrestrained as that of Fabius and others, but also that contemporary philosophies such as Stoicism, are not necessarily the only guides to responsible behaviour. He believes that a return to the old Roman values might contribute to greater political and social stability and coherence. Thus, the opening of Horace's first book of Sermones contains two important statements relating to his efforts to convince Maecenas: he asserted that he held the right political views, which were not those held by the extreme Stoics, of whom many were Octavian's opponents, and he adds to this the positive statement that the old Roman values are the foundation of his outlook upon life. 
The main part of S.1.1 (lines 28-107) is taken up with further detailed descriptions of greed, ambition and extravagance of distinct groups enabling Maecenas to judge the poet's convictions. At first, he returns to the subject with which he opened the poem: the discontent of many people, envying others. The discontented farmer, innkeeper, soldier or sailor have one thing in common, that is their desire to get rich and enjoy a comfortable retirement when old. Next, Horace censures greed for the following sixty-six lines asking the miser what the use of all his hidden silver and gold is. Horace explains that man ought not to cross natural borders, and that man does not need more food and drink than his body can cope with. He suggests that when a man lives in harmony with nature it does not matter whether he ploughs a hundred or a thousand acres, as long as he can take all he needs from the smaller piece of land. He also gives a forceful impression of man's greed and the consequences of stepping outside nature's bounds in the allegory of the man who needs a cup of water, but takes the cup from a wild river rather than from a tiny brook. Their greed makes them blind for the burden of amassing more riches than one needs. Similar to Virgil's placing the events described in Ecl.10 in his native area by the functional reference to the river Rhenus, Horace also uses a functional reference to the Apulian river Aufidus to locate in his native area the allegory of the greedy man having a drink. It is feasible that Horace refers here to what he experienced in his youth, when the greed and arrogant conduct of the new class of rulers, the military, called the shots in Venusia, and consequent destruction of the traditional social structure of his home town.

The poem started with the poet criticizing average citizens, like traders, sailors, soldiers, farmers, lawyers, innkeepers, but moves away from those towards misers, who, obsessed by their fear of losing their money, belong to the increasing group of nouveau riche. I come to this view on grounds of the specific choice of words. Using the words "a good many men (bona pars hominum)," Horace indicates that rather many people think that one cannot have enough. He wrote bona pars because he observed that this thinking was particular manifest within the large emerging group of the new rich, rather than in the circumscribed group of the old rich. In addition, Horace's rejection of the ways of the new rich is also a theme in each sermo of S.1, except in S.1.8. He points out that wealth cannot buy health, happiness or love. The miser is left to his own devices in times of sickness, even by his wife and children. Neither should one run to the other extreme, that is behaving as spendthrifts, who show their wealth. It is feasible that Horace makes a point of presenting these types as representatives of the new class of the rich, who could afford the most extreme opulence and indulge in excesses. Horace finishes S.1.1 with the conclusion that knowing when to stop is something that the greedy and ambitious men, for whom enough is not enough, never do. Horace warns them of the limitations in their search for power and wealth suggesting that they should follow the example of the well satisfied dinner guest, who does not stuff himself. He brings in the last line the Stoic Crispinus on the stage, that is in the role as an adherent of Sextus Pompey, a connection that Horace will examine at different places in S.1. 
Horace's mention of avarice and ambition throughout the poem is significant. Horace depicts himself and Maecenas as very concerned about the erosion of moral standards, and its impact on the political situation. Horace attacking the vices of avaritia, ambitio and luxuria reacts to the contemporary hostile propaganda against the Triumvirs, principally, of course, Octavian. Censuring greed and ambition, he expresses a most likely widely held view in Rome that the greed of the powerful has led to the contemporary problems of civil war and political and social strife. In his opinion, however, it is the greed of the powerful from different layers of society (aristocrats, the new rich, freedmen and the military) that caused the contemporary problems, and not only the actions of the Triumvirs or Octavian. Further, the allusion of the final lines of S.1.1 to those of Ecl.10 is significant as Horace achieves two objectives by these final lines: firstly, a statement about his approach to writing poetry, namely that he does not carry on endlessly, but knows when to stop, and secondly the delivery of the message which the book of Eclogae expresses, that is a critical commentary on contemporary state of affairs. As it were, Horace associates himself with the political views of Virgil, who introduced him to Maecenas, and demonstrates thus that he is one of them. I interpret the two functional references, the one at the end of Virgil's Ecl.10 and the allusion to the Aufidus, as Horace associating himself with Virgil's condemnation in each ecloga of the expropriations and the expulsions in Italy and of the destruction and social upheaval caused by the civil war and its aftermath. One may wonder why Horace joins Virgil through those hidden allusions, and why he does not speak more openly. I suggest that at the time of writing S.1.1 Horace did not want to bring to light too openly a critical view of Octavian's involvement in the struggle for power. The outcome of the civil war was still undecided. Horace may have felt that as a new man in Maecenas' circle, blemished by his former allegiance to Brutus, he did better not to speak in his first poem too openly about delicate major political subjects in Maecenas' presence.

Horace introduces in S.1.2 a man called Tigellius, who together with one called Hermogenes feature in a number of places in S.1. I examine the issue of their identities in the opening of my analysis of S.1.2., and I come to the conclusion that Horace wrote about two different men: about the dead Tigellius in S.1.2 and S.1.3.4, and about Hermogenes at other places (S.1.3.129, S.1.4.72, S.1.9.25, S.1.10.18, 80 and 90). The difference between the two is important as the Tigellius (of S.1.2), who is praised by his entourage for his generosity, is a prototype of a playboy in first-century B.C. Rome, and symbolizes in S.1.2 the faults of the Roman patronage system which buys secondrate loyalty. Hermogenes symbolizes the many who tried to force their way into the social and political elite and exemplifies unreliability (see S.1.3.129).

Horace gives examples of people who do not know their border and who search for the extreme in financial matters being either a spendthrift or a miser, and for that in sexual exhibitionism in public. In the remainder of the poem, the lack of a middle course is also very apparent from the ways of men who do not know how to choose wisely their preferred ways of sexual gratification. They go for either the extreme 
of adultery with a married woman or for that with a prostitute. Horace suggests the middle course: satisfaction of one's desires on a casual, dispassionate basis with a freedwoman.

Next, Horace introduces the sexual scandals of Roman high society. One of the scandals he refers to is that of an affair of a Marsaeus with an upwardly mobile mime actress. Horace condemns the lack of restraint of Marsaeus' extravagant conduct squandering his father's inheritance on his mistresses. The reference to a mime actress is especially of interest, as at the time mime actresses were favourite girl friends of upper class men, and the affair mentioned may allude to the affair of Marc Antony with Cytheris. Horace did not express his disapproval of Antony's affair, but he censured Antony's behaviour which was typical for the degeneration of standards within the elite. He explains the advantages of seeking sexual gratification with a prostitute or a woman, not a married woman (matrona) who is available. A prostitute shows openly what she has for sale, whereas a matrona can show off her attractive bodily parts and hide the less attractive. Thus, seeking the pleasures of a matrona is like the rich men's practice of buying horses that are covered up for inspection. Horace compares a genuine Roman lover to a genuine hunter who follows the hare in deep snow. But, he appreciates that he should give a realistic advice for satisfying man's sexual desires, and he gives his views on the best choice. He introduces an Epicurean analogy to separate unreal pleasures from real ones, by distinguishing the void from the solid. He continues the Epicurean analogy comparing the pains of sexual desire with hunger and thirst. When one is thirsty and hungry, a simple meal will do. He calls in the Epicurean Philodemus' aid who says that he wants for himself a woman who is available, although not for a high price, and does not hesitate to come when bidden. Philodemus wants something between a prostitute and a matrona: a freedwoman. Finally, the poet repeats his advice not to seek a matrona as there is always a chance of being caught out.

Horace places the events of the second satire clearly within the Roman upper class. He introduces two groups of men. The first group belongs clearly to the aristocracy or at least to the political/social elite (Galba, Sallust, Villius, Longarenus, Fausta), and the functional reference to Marc Antony. The second group is that of the wrong men within the retinue of Roman patrons (Tigellius, Cupiennius, and the nouveau riche Fufidius). The disdain with which he generally writes about a nouveau riche is very different from the note he strikes in this passage writing about the members of the aristocratic class, how much he may disapprove of their actions. A number of other allusions also supports the conclusion that we are seeing the upper classes in action. The second half of the poem does not have many names, but has a number of references to the lifestyle of the upper class: the buying of horses, the servants of the lady, the leisure pursuit of game. Although it seems that S.1.2 concerns chiefly the pursuit of sexual extremes, Horace's commentary covers the broader field of the common and unmannerly conduct of an increasing number of members of the upper class. At the time of Horace writing this sermo, a development of the structure of the 
Roman and Italian social upper layer had materialized in new classes of rich people besides the traditional optimates, the old aristocratic families and landowners, from whom the members of the Senate and consuls were recruited. Apart from the lack of restraint of an appreciable number of aristocrats, Horace also addresses, like in S.1.1, that of the growing group of new rich. S.1.1 and S.1.2 share the same self-presentation: Horace makes it absolutely clear to Maecenas that he does not want to know that sort of people.

In S.1.3, Horace opens his discussion of how to communicate by presenting a probably fictitious story situated within the private bounds of a circle of friends. The story of obstinate Tigellius who did not want to sing and Octavian who restrained himself to force the singer demonstrates that people cannot be forced to speak and listen. Horace continues stating that Tigellius and others are the kind of people with whom he would rather not associate and communicate in his circle of friends. Tigellius is inconsistent and hypocritical, Maenius a shameless parasite, although of good parentage but a rather self-loving spendthrift, and Novius an unknown upstart.

Next, Horace considers the style and manner delivering his commentary in the future. Horace's lines are not those by a clumsy and inexperienced philosopher and moraliser but describe his clever strategy as to how to conduct himself in the highly politically charged environment of the post Republican era and emerging Principate. He considers how to deliver critical commentary in general, in the role as a commentator of political issues in several genres. He depicts the potentially most effective manner in which to convey his critical and potentially antagonistic commentary on contemporary social and political issues: the gentleman who adopts some of the manners of a jester. Horace does not wish to present himself as a buffoon, as he sees such a character as uneducated and vulgar. He wants to position himself as a gentleman commentator who does not shy away on the one hand from the humour and on the other from a sense of perspective. His style is not that of the professional jester of the comic stage, the scurra. Horace is in the Sermones not just simply a mixture of the seriousness of his political commentary with humour, but a mixture with a special kind of humour. Horace as a Cynic jester is the gentleman who can raise the touchiest issues hiding himself behind a façade of naïvety and simpleness. By this he can also make opportunity to vent the opposite or controversial political opinion, without taking sides.

Horace wrote $S .1$ as material for discussion with Maecenas and his associates, whose friendship he hoped to secure. Hence, he pays attention in the present poem to the subject of understanding one's friends. He gives examples as to how friends' faults can also be understood positively, and thus friendships can be strengthened. In S.1.3.63-66, he presents a second self-parody, a character sketch of an intruder. The passage has an ironical disapproval of the facetious conduct of the jester, who suggests that he can afford almost anything, knowing that Maecenas will accept such behaviour, as masters of jesters do. The passage is also a sequel to S.1.3.29-34. Like the earlier passage (S.1.3.29-34), this one is not autobiographical, but a further 
specifying of the way Horace intends to present his messages in the first book of Sermones. Horace does not depict himself in those two passages as either a clumsy provincial bumpkin or as a social menace, but he presents himself as a gentleman jester who takes the liberty to tell Maecenas whatever he thinks that the latter should hear. He also states that Maecenas knows how to handle those people. These lines also anticipate S.1.10.46-49 in which he says that he does not intend to become the successor to Lucilius.

Next, from line 76, the argument moves away from the single theme of tolerance of the faults of one's friends. Horace introduces the theme of balance (or the lack of it) in the execution of justice in society at large. The argument also moves gradually towards one with a philosophical (lines 76-98) and a historical (lines 99-124) angle. At first, Horace argues that the Stoic view that all sins are equal and deserve equal punishment is absurd. He gives examples of what he considers an excessive sanction for a minor misdemeanour. Horace appeals in lines 77-83 for reason (ratio) and balance (ponderibus modulisque) displaying in a subtle way his Epicurean disposition with the choice of words ponderibus modulisque (weights and measures): words associated with the Epicurean tendency to quantify and measure. By quoting the words ponderibus modulisque, he shows Maecenas that he holds the right philosophical convictions. Horace mentions more examples of offences among friends in order of increasing gravity, from harmless infringements of table manners to more serious delicts by friends such as theft or reneging on a legal pledge. He seizes the opportunity in lines 97-98 to demonstrate again that he is not a follower of the Stoics stating that their answer that all sins are nearly equal does not work in reality. Emotions, the moral sense of people, and custom are opposed to it. But, a link with his own Epicurean socio-political attitude appears when he concludes with the statement that justice and fairness are sisters.

Horace turns in lines 99-124 again to Epicureanism to expound his views on the history of civilization and the origin of justice and fairness in contemporary society. He dismisses again the Stoic doctrine. Horace argues that the system of justice is the crown of the development of a civilized society and that tolerance, balance and wisdom should be essential elements of such a system. This leads him to the question of the choice of men who should be the leaders in society. Horace places in this passage acceptance of or intolerance to friends' faults and also extremism in the execution of justice within the context of Stoicism and Epicureanism. Further, he connects his commentary with the emergence of new men within the political elite, who are driven by personal gain. What matters are not only Horace's statements about friendship, tolerance, fairness, or balance, but also the men who make those statements or the men to whom Horace refers. By exploring the social and intellectual standing of those men, he concludes that the wrong men, new rich and upstarts have gained too much influence. Horace introduces many individuals in this poem, who can be divided into two groups. The first group is that of his friends, whom the poet quotes consistently in a positive manner in this sermo. In other words, Horace's aristocratic friendships 
are models of amicitia. The second group shows the opposite image with the names of the inconsistent singer Tigellius (line 4) and unreliable Hermogenes (line 129), shameless Maenius, a spendthrift from the past (line 21), the upstart Novius (also line 21), deranged Labeo, probably a Republican tribune of the plebs (line 82), Ruso, a moneylender and aspiring author (line 86), and Alfenus, most likely corrupt P. Alfenus Varus (line 130). It is worth noting that the discussion about how to judge one's friends is between people, who all - apart from Alfenus Varus - fit the category of nouveau riche or other upstarts. Further we meet the Stoic Chrysippus (line 127), who is gently mocked, and finally there is Crispinus (line 139), the Stoic babbler. They generally take the "wrong" view as to how to treat one's friends, and support Stoic ideas about the execution of justice.

Horace ridicules in S.1.3.124-142 the Stoic paradox that only the wise man (sapiens) was perfect and thus rich, free, beautiful and talented. He plays a very clever game in this passage. He does not only hold up to ridicule the paradox, but also censures the Stoics for the results of the paradox in the choice of leaders and thirdly he can, as an extra benefit, demonstrate to Maecenas, that they share the same philosophical framework thus subscribing to the same views on political matters. Horace plays in this passage three times upon a word to caricature the Stoic paradox. The first is sutor (cobbler) in lines 125 and 128, the second modulator in line 130, and the third is tonsor (barber) in line 132. The sapiens is caricatured by the poet in lines 124-128 as being an expert cobbler, and one may wonder why Horace chose the humble trades of cobbler, and in line 132 that of barber, for making his point; both trades were low in the social scale. Horace chose those because he wanted not only to express the absurdity of the potential of the opportunities for the wise man in the Stoic paradox, but he also wanted to play upon the words sutor and tonsor. The word sutor, generally translated as cobbler is derived from suere, to stitch or cobble. The latter word suggests patching-up something, working hastily and delivering shoddy work. In other words, Horace says that the Stoic's claim is absurd and that they make a mess of things: the Stoic view leads to the selection of the wrong people at high positions in public life (lines 128-133). What else do the Stoics mess up? The extreme Stoics, anti-Caesarians and followers of the Pompeian cause, stood in Octavian's way and obstructed the latter's progress towards peace and stability. Then, Horace uses the word modulator for Hermogenes. In the words of Freudenburg (1993, 116), Hermogenes of line 129 has a remarkable ability to "change keys" or "adjust" himself to the changing political winds. According to Freudenburg $(1993,114)$, the third word tonsor refers to P. Alfenus Varus, consul suffectus in 39 B.C. and jurisconsult. Paraphrasing Freudenburg the lines can be read as: Alfenus, even though he has sold his shop to become a lawyer, is still the same old shearer [that is, crook] that he always was. The references in S.1.3 to Hermogenes and Alfenus symbolize the many who tried to force their way into the social and political elite. The poet did not intend to make a philosophical statement about the wrong of the Stoic ideal that the wise man (sapiens) is perfect and talented. The three keywords, sutor, modulator and tonsor, all point in the same direction. 
Horace had in mind to demonstrate that men like Hermogenes, who exemplifies unreliability, and Alfenus, who shows untrustworthiness and dishonesty, should not be welcome into the political and social elite, and are not deserving to hold office: Hermogenes who defected to Sextus, and Alfenus Varus who was "ripping off" the poor smallholders in Northern Italy. Horace emphasizes the moral and intellectual failure of the Stoic paradox once more by the pitiful picture in lines 133-139 when Horace depicts the Stoic philosopher on his way to have a bath on the cheap mobbed by a hostile crowd of men, with whom the poet does not wish to be associated. The escort of the wise man, alias king, is only Crispinus the Stoic babbler.

Although at one level S.1.3 concerns indeed the conduct among friends specifically the judgment about the inconsistency and hypocrisy of one's friends - the poem also contains a second point, that is how a message can be presented within a circle of friends, while at the same time preserving tolerance and dignity among the participants. Horace's choice of participants and subjects in S.1.3 reveals the philosophical foundation of the poem: like he does in S.1.1 and S.1.2, he follows in the present sermo the Epicurean views and rejects Stoicism, the popular philosophy of those who supported the Republican cause. The Republicans and Pompeians adopted the widely held opinion at the time that the Triumvirs - and Octavian and his associates in particular - did not act from high moral principles at all but from avaritia, ambitio and luxuria, which were seen as the cause of Octavian's hunger for power. In S.1.1-1.3, Horace shows his concern about the general growth of reprehensible urges like greed, unlimited ambition, and pursuit of luxury. In addition, Horace divides in S.1.1-1.3 his audiences in three distinct groups: the elite, the nouveau riche and the extreme Stoics. He singles out some of the aristocrats, new rich and other upstarts as unfitted for political office. Thus, the three sermones are political poems as they are in support of Octavian and his policies against the Republican adversaries. His circle of friends ought to set a good example by living according to the high-minded principles of the past. Horace closes S.1.3 with a few lines (139-140) about his own fortunate circumstances. He confirms that he felt accepted within Maecenas' circle of civilised leaders.

Horace starts S.1.4 with a discussion that seems to be a rejection of Lucilian satire, but that can also be read as Horace's standards of good poetry: brevitas and libertas. He sees as standards of good poetry sharply worded thoughts and freedom of speech. The poets of Old Comedy possessed those attributes. Horace charts in those lines characteristics which apply to several genres of poetry, not only satire. Many of the points which he raises in S.1.4 return in S.1.10, where he adds a third attribute, varietas (variety of presentation). In S.1.4, he pays attention to the subject of freedom of speech and its connection with $\pi \alpha \rho \rho \eta \sigma i \alpha$ (parrhesia) and the teaching

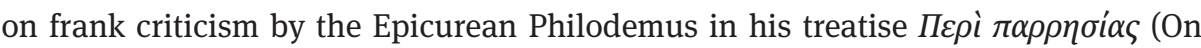
Frank Criticism). Horace recognizes two sources of inspiration for his moral guidance: the notion of parrhesia and the traditional Roman moral values as handed down by previous generations, mos maiorum. In his opinion, parrhesia is relevant both in the 
public and in the private domain. Horace reflects on frank criticism among friends; he follows the teaching by Philodemus (On Frank Criticism) in carrying into effect his criticism, and he sees mos maiorum as his moral guide of conduct among friends. The two go together. Horace accentuates the importance of freedom of speech in the public domain. He records in S.1.4 with approval that the poets of Old Comedy censured with great freedom of speech, and thus Horace stood up to the Pompeians, who claimed to be the defenders of Republican libertas. Horace assured that he, like his associates, was also fully committed to support freedom of speech.

Horace introduces in S.1.4 a new class of people for criticism, in addition to the classes he singled out for criticism in S.1.1 - S.1.3. He describes the behaviour of common people that appears to be the same as that which he saw in the upper layers of society in S.1.1 and S.1.2. In S.1.4, he extends the class of people deserving censure from the elite to all classes of Roman society. He seeks to convince Maecenas that he recognizes social evil in society at large. He does not exclude any section of Roman society from his scrutiny. Horace is specific about the mode of delivering critical poetry, firstly to friends, secondly to a group of men who are within the retinue of a patron, and thirdly to some members of the elite. He presents a catalogue of malice that cannot be tolerated among friends, who should frankly criticize each other when necessary. Horace repeats his view that there is no place for the many new rich who try to force themselves into holding high office and are not deserving such.

S.1.4 is seen by several scholars as defensive poetry. Horace's reflections on the style and content, such as ingenium, ars, res, verba and metathesis, are not primarily the result of his search for his poetic orientation, but are part of his discussion about his political orientation with Maecenas and his circle. His pronouncements about the satiric genre are markers for his political and social views intended to convince Maecenas that he holds the right political opinions and that he has the right social background. Horace, an unknown man from provincial Venusia, wants to demonstrate that he is a reliable member of the circle of Maecenas. Thus, he has to demonstrate that he is of good political stock, that upholds the traditional Roman values, and that he shook off the last vestiges of Republican leanings.

Horace went in lines 1-105 into his programme of writing critical commentary. After line 105, he changes to personal aspects, namely his education and his outlook upon life. He presents this in the form of part of "his autobiography," of which more is to come in the next sermones. In my view, this part of S.1.4 - and indeed the other putative autobiographical passages in the following poems - is predominantly poetic fiction. "His father" symbolizes the tradition in which Horace grew up. The role of "the father" in the narrative is that of a link between the generations symbolizing the continuity of the traditions. He describes in the same sequence as in S.1.1 - S.1.2 how he learned that he should avert the vices of S.1.1, jealousy, greed, ambition and extravagance, followed by the vices of S.1.2, sexual extremes. In this way S.1.4.107-115 is a summary of the first two sermones. He learned that he does not only want to be guided in moral matters by the teachings of philosophers, but also by following the 
traditional Roman moral teachings handed down to him: the mos maiorum was of great importance to him. Horace finishes the poem with a confident statement that he and a number of his poet-friends within the circle of Maecenas have an important contribution to make to the debate about the major contemporary political and social issues.

It is unlikely that $\mathbf{S . 1 . 5}$ was written as an exercise in emulating Lucilius' Iter Siculum. The sermo is the poet's next step in presenting himself as a worthy member of the group of men around Maecenas. In my view, it is also unlikely that $S .1 .5$ is an autobiographical poem. The purpose and the dating of the "journey" are uncertain, and the lack of information about the context of the mission suggests that Horace never was a member of such a mission in reality. In addition, the authenticity of the "journey" is suspect, particularly on grounds of the differences in content and detail of Horace's description of several parts of the voyage and the route of the journey. The composition of the narrative shows a remarkable difference in detail and in extent of information about the places visited between on the one hand the first part of the "journey" from Rome to Apulia and on the other hand the part from Apulia to Brundisium. Descriptions of places such as Aricia, Pomptine marshes, Formiae, Caudium, and the activities and encounters of the party are full of particulars. However, the description of Apulia in part two is with respect to both the route and the places visited unclear. The report of the four towns of the last part, the 104-miles stretch from Rubi to Brundisium is very brief, and the most memorable matters on that section seem to be the weather and the condition of the road. I conclude that Horace's description of the part of the "journey" between Rome and Apulia is reasonably detailed because he made the journey between Venusia and Rome at several occasions; the stretch between Rubi and Brundisium he had never seen at all.

Horace pays special attention to Venusia - referred to as an oppidulum (small town) - and the Apulian region, although only by a brief allusion. He kept his description of the route of the Apulian part of the "journey" deliberately unclear, as he wanted to focus on the quality of his upbringing in Venusia through his metaphor of the quality of the bread. He refers to his milieu in the present sermo as he did in S.1.4 and will do so again in S.1.6. The milieu to which he referred is his own ancestry representing the link between the generations and symbolizing the continuity of the traditions. He grew up in a family having respect for the old Roman values.

His aversion of new rich and pretentious dignitaries in small towns is very evident. Examples are Aufidius Luscus, the chief official of Fundi, rich Mamurra in Formiae, and the scurra Sarmentus in Caudium. This is in great contrast with the appreciation he has of the leaders of the supposed party, Maecenas, Cocceius and Capito, whom he considers his equals, and the joy of being with his friends, Plotius, Varius and Virgil. On three occasions, he distances himself of provincial attitudes, namely the "praetor" Aufidius, the base humour of the show of Sarmentus and Cicirrus, and the miracle in Gnatia. Horace shows again a contrast with the low-minded provincials when he mentions Sinuessa in the region of Naples alluding to his own association and that of 
Maecenas and his friends with Philodemus. He intends to be a worthy member of the circle of Maecenas assuring him that he does not want to associate with the nouveau riche and that he also left the provincial milieu behind. He upholds the traditional Roman values handed down to him. He wants Maecenas to know that on grounds of his descent, education and personal development he is well qualified to become a worthwhile and reliable associate of Maecenas. The manner in which he presents himself to Maecenas as a fictitious companion in a fictitious journey also illustrates his contentment with the reception by Maecenas and the members of his circle. This theme returns in S.1.9, which has much in common with S.1.5 in structure and theme.

In the first section of $\mathbf{S . 1 . 6}$ (lines 1-44), Horace raises the subject of mobility between social classes. The opening of the poem recalls that of $S .1 .1$ by addressing Maecenas. The poet introduces immediately in the first lines Maecenas' social background. Although the latter was not of Roman nobilitas, but of Etruscan, he fitted well in the top of Roman society; several scholars point out that Maecenas was socially not much above other upstarts who formed the majority of Octavian's supporters. They originated in the provinces: Maecenas in Arretium, Agrippa not known where he was born, but not in Rome and Octavian himself born in Latium. It is not unlikely that Maecenas overstated his social position by posing of nobler birth than he was. Horace saw his own social position as not very different from that of the "Etruscan prince." The poet pays Maecenas a compliment by stating that he did not forget his roots and reveals an enlightened view on social mobility. It is unlikely that Horace would have made the point that Maecenas and he are both upstarts if he had not irrefutable evidence from Maecenas' past. Having concluded that Maecenas and he are socially equivalents, Horace recognizes that Maecenas shoulders greater political responsibility than he. Most members of Maecenas' social rank have a prejudiced view of social mobility seeing the new men as a threat to their own traditional place in society. Horace resented indeed the men who exhibited an unrelenting ambition for office with the rewards belonging to it, but he accepted that men who aspired for office should be judged on their individual merits. Horace observes approvingly that Maecenas is generous in his judgement of peoples' worth.

Horace records the pros and cons of social mobility going back to the days of Servius Tullius. He describes the miserable quality of the process of determining the eligibility for political functions. He concludes that Maecenas and he should continue judging people on their own merits. Horace also states that he himself wants to stay out of practical politics, and he lets Maecenas know that his interest in political issues is not caused by political ambition.

Next, Horace pays attention to the endeavours of men of his own days to gain office. He endorses the view that the nobiles on grounds of inherited worth (virtus) through birth have a valid claim to be selected for high public office, provided that they are not disqualified by lack of individual worth. If they are disqualified, it is preferable to elect worthy free-born homines novi (new men) to unworthy aristocrats. Horace rejects again emphatically the pursuit of ambition often seen with men who 
strive to gain high office and who seek to further their own, financial, interests. He gives some examples as to how people, for example a man called Tillius, can go wrong when they yield to the temptations of ambition. Tillius cannot be identified, but in view of the context of S.1.6 it is likely that he symbolizes an ambitious freedman's son, who had an erratic political career. The Tillius of S.1.6 may well be Horace's fiction, who was not modelled after a historical person. Horace made him an embodiment of political ambition leading to his ruination, with other attributes added, namely a man of humble descent or a freedman's son.

Horace closes the first section of S.1.6 with a discussion about the political careers of freedmen and freedmen's sons. He refers to the prejudices of the established political elite that the new men are not qualified to carry out their duties properly and to the resentment of free-born men at the promotion of ex-slaves or their sons to high public office. However, there is also much ill-feeling between freedmen's sons and freedmen, as the example of the freedman Novius shows. The social distinction between the two is that the latter was once a slave and that the former may be "free-born." A new class-consciousness had crept in, namely that the new generation of freedmen has come too near to "the old," the sons of freedmen of the previous generation. However, Horace shows the relativity of this: the freedman Novius will never match the social standing of the aristocracy. Horace makes a political point mentioning two aristocrats specifically, Paullus Aemilius Lepidus and Valerius Messalla Corvinus. Those men were at the time two of the few supporters of Octavian to be found within the old aristocracy. Most of them supported Marc Antony, or even worse, Sextus Pompey. Octavian needed the support of the Senate which traditionally was dominated by the nobiles. Hence, Maecenas, and with him Horace, supported the claims of the old aristocracy that birth was an important qualification for high office. Horace's view on social mobility and eligibility for high office is in short: give talent a fair chance, but the real work will go to the traditional upper class, as birth remains the determining factor. Horace also gives in this section his arguments to stay away from the political business, as a career in politics would not make him feel good.

In the second section, Horace changes into the personal mode. The section opens in line 45 with the famous words: nunc at me redeo libertino patre natum (now to return to myself, son of a freedman father). He refers to his past when he was a tribune in Brutus' army and fighting at the wrong side at Philippi. He recounts Maecenas' good judgement accepting within the circle around him men who shun improper ambition, those who do not pursue high political office motivated by avaritia, ambitio and luxuria (greediness, ambition and extravagance), as he saw with many of the new rich. After these opening lines, he reports the introduction to Maecenas by Virgil and Varius and the resultant brief first meeting with Maecenas, in which both were rather reticent. Horace because he felt embarrassed and Maecenas as this was his way. In my view, these lines are not simply autobiographical, but a combination of autobiography and poetic fiction. The point is that Horace does not present himself as a nouveau riche aspiring for the friendship of Maecenas. Both are depicted as recognizing the 
cultivated manners of the other, and they would not need many words to understand each other. Contrary to the nouveau riche, Horace is embarrassed: presumably not by his social status, but by his association with Brutus' party in the past.

Horace uses three times the words libertino patre natum (a freedman's son): in S.1.6.6, 45, 46, and a slight modification in line 58: non ego me claro natum patre (that he was not the son of a famous father). The emphatic reiteration of this point tells us that he, a son of a freedman himself, endeavoured to advance and to be found acceptable to Maecenas and the circle around him. That is his way of social mobility. In my view, Horace's words about his putative humble origins do not mean that he, like Bion of Borysthenes, was telling Maecenas that the latter needed "a truth-telling philosopher” and that he, Horace, was such a man. Although Horace's occasional references to philosophical dogmas were basic to his ethical socio-political views, he did not promote himself as an adviser on philosophical doctrines.

In S.1.6.69-71, the poet adds to his own self-praise referring to "his father's" role: purus et insons/ (ut me collaudem) si et vivo carus amicis; / causa fuit pater his (if, to blow my own trumpet, I live a pure and innocent life and if I am cherished by my friends, this is because of my father). Next, the story about his father taking him from Venusia to Rome follows. Horace makes not only the point that his father was not rich, but also that he did not belong to the emerging class of provincial new rich. He refers to several aspects of his social and cultural background which should build up Maecenas' regard for him. He mentions in this short section his father's parsimony, his own departure from provincial Venusia, and his good education in Rome. The father was involved as he felt responsible for a good education, but did not want to be his son's one and only moral guardian. Horace said in S.1.4 that the traditional way of life is handed down to him by the Roman forefathers. The role of "the father" in the narrative is a link between the generations symbolizing the continuity of the traditions. Horace says both in S.1.4 and in the present lines of S.1.6 that the right way of life was handed down to him by good Romans in general, by his milieu in Venusia and that of the social elite (eques atque senator) in Rome during his time with his teacher Orbilius, fond of flogging. That is probably where he also picked up the right political ideas. In my view, parts of Horace's narrative about "his father" are poetic fiction. Some elements are indeed autobiographical, for example that he grew up in Venusia or nearby the place, his education in Rome with Orbilius, but the details of his "father's" role are most likely made-up in order to make his background suitable for his association with Maecenas: Horace, the man from provincial Venusia on the one hand holding the right traditional values, but on the other hand familiar with the sophistication of Rome. Yet, he succeeded in remaining uncorrupted, which is virtue's first credential. Thus, Horace connects in this sermo on the one hand the issue of social mobility, described by him in the first section of S.1.6, with on the other hand his moral credentials and the teaching by his milieu, described in the second section. 
In the third section he considers his own prospects. Horace states right at the start that he does not foster political ambitions. He would not want to replace the naturalness and cultivation of his milieu by the insincere distinctions of high office. He wants to stay out of practical politics as he does not wish to lose control of his way of life, to lose his personal freedom. He mocks the life of the nouveau riche who aspires for political office and who shows off his wealth. Next, Horace gives an impression of a typical day in his life. It is all very prosaic and not so pretentious as the entertainments of the nouveau riche. But, he is grateful that he is not obliged to participate in the duty of paying morning calls to a patron. He enjoys his intellectual pursuits of reading and writing and discussing the output within the circle of Maecenas of his friends and associates. In my view, the passage about a typical day should not be read as autobiography, but as Horace's fiction in answer to the many examples in this sermo and in previous ones about the behaviour by many of the new men in politics and by the new rich. Further, the typical day is not a proof of his Epicureanism, although his Epicurean views made him aware that he needs the freedom to organize his life in his own way to be able to reflect and study. Cicero criticized the Epicureans severely for their selfishness and consequent tendency to avoid political life. He saw this as a serious threat to the survival of the state. Horace does not say that he aspires for being an outsider in Roman politics, but he seeks to participate in his own way as a commentator. If he is involved in politics from the sidelines, he needs his independence in order to be free to say what he must.

Horace closes S.1.6 expressing his gratitude that he is not the son of one of the established families, that would have deemed him to pursue a career in politics and probably finish as a senatorial candidate.

Horace changes the emphasis in S.1.7 (and indeed in S.1.8 and S.1.9) compared to the previous six sermones. From S.1.7, he sounds confident that he will succeed in his efforts to find a place within the circle of Maecenas. He juxtaposes in S.1.7 the cultured milieu that he experiences after being admitted to Maecenas' circle and the crude and aggressive one of his past with Brutus, thus admitting in the present sermo openly his previous association with the Republican cause. This makes S.1.7 a poem with a special meaning. Horace chooses as his subjects for discussion strategic issues of military and foreign policy. He does this presumably in order to demonstrate that he also has a contribution to make in those fields and again to show that he supports the policies of Octavian and Maecenas. On the face of it, the subject-matter of S.1.7 seems to differ from that of the other poems in $S .1$, namely that it seems to be concerned with events from the past that have no bearing on contemporary political issues, let alone that the poem can be read as one of his credentials. However, the poem can be properly interpreted as one of those.

Horace goes some five to seven years back when he narrates an event that he claims took place after he had joined Brutus in 44 or 43 B.C., and before Philippi and the death of Brutus in 42 B.C. That does not mean that the story is an account of a real historic event; in my view, it is one of Horace's fictitious narratives. He describes a 
probably fictitious court case that was held before Brutus as the presiding judge and concerns most likely a tax issue between Rupilius Rex, a tax official on the staff of Brutus, and the businessman Persius. Many like Rupilius were tax-gatherers who were known to line their own pockets with considerable amounts. Persius was presumably assessed by Rupilius for such an absurd amount that it pruned away his profits. The case finished with an angry verbal combat between the two in front of Brutus and an improper insinuation to the latter.

The scene reflects the lawless situation in Asia resulting from the unresolved Parthian issue. Firstly, the name of Persius may well be a functional reference by Horace to the continuing Parthian influence in Asia Minor. Secondly, the confrontation between the Lycian ally of Troy Glaucus (of Iliad.6) and the Greek Diomedes probably refers to the contemporary conflict between East and West, and the arrangement which the two men conclude can infer that Horace suggests that negotiations with the Parthians should start in order to solve the Parthian problem: a course that was followed by Octavian after 27 B.C. Thirdly, the final lines of the poem reinforce this interpretation. The lines are a personal attack on Brutus and this humiliating scene was the result of Brutus' incompetence: seen to be enjoying the sumptuous life of an Eastern court, but not commanding the respect that a Roman official deserves. Brutus was removed at Philippi in 42 B.C., but Horace reminds his audience in this poem six years later (in 38 - 36/35 B.C.) that it's the same old story over again of a Roman official who lives at the court in Alexandria and whose military and administrative achievements are minimal: Marc Antony's fiasco in Parthia and his submission to Cleopatra's ambitions of their own imperium in the East are a threat to Rome. Further, the enrichment by many officials still prevails in Asia, and nothing is done about it. Marc Antony ought to be relieved of his military and political responsibilities having mismanaged those.

The subject of $\mathbf{S . 1 . 8}$ is also a major contemporary issue, like in the previous sermo. In the present poem it is the threat of magic, that had penetrated Rome's lower and upper classes. Horace describes the activities of the witch Canidia and her companion Sagana on the paupers' graveyard on the Esquiline, which will be transformed into beautiful gardens by Maecenas. Priapus has a principal part in the drama. He was originally a fertility god from Lampsacus, opposite Gallipoli. In addition to the god's traditional role as guardian of gardens and tombs and that as one expelling evil forces, like witches, Horace gave Priapus the new role as his spokesman, and that as a figure that alludes to Cleopatra and Antony (see below).

Horace fills half of the poem with the witches' horrible activities. He wants to impress upon us the terrible wickedness and dangers of black magic. Through the medium of Priapus, he depicts in those lines a scene that could be seen at many places in Rome and in Italy. Horace himself does not feature in the poem. The reason is that Horace never experienced such a séance, but that he retells what he learned from others: witnesses' tales of the customary forms of black art, such as necromancy and psychedelic experience, and tales of the core business of witches aimed at winning 
over a reluctant lover for which the witches were handsomely paid. The psychedelic scene that Priapus just witnessed evokes his fear to such an extent that he no longer can control his bodily functions. The scene also radiates a sense of degeneration. Horace indicates that those meetings are out of place in modern civilized Rome, the centre of the world.

S.1.8 should be read together with Epod.17, in which Horace continues the story thus presenting significant indications about the meaning of S.1.8. Epod.17 gives some clues with respect to the source and nature of Canidia's magic. Firstly, it can be deduced from the epodos that Canidia celebrated at the Esquiline Cotytto's festival, a deity of Thracian origin related to Artemis-Bendis, whose rites were secret licentious activities characterized by extreme wantonness. Secondly, although Horace wrote the epodos in the first person and although he seems obsessed by the power of Canidia's magic, he did not intend to intimate that he personally suffered by her magic. In general and also in particular in Epod.17, Horace does not necessarily relate real-life experiences using the first-person persona.

Several additional arguments can be found in the epodos against the views that Canidia exercised sexual control over Horace and that he personally revelled wantonly in the acts of free love. The characteristics, of which victims of Canidia are supposed to suffer according to Epod.17, are not apparent from Horace's work and way of life. Horace voices in Epod.17 the generally felt concern caused by the widespread sorcery that appeared to still be ongoing in Rome as if the measures taken seem to had no effect. Horace himself is not a participant in those sexual games, and it is feasible that his Canidia stories are poetic fiction. Horace suffers by substitution the mental and physical torments of the victims of sorcery. This is not to say that the kind of sessions described did not take place in Rome. It is not unlikely that what we read is the result of hearsay, although it is feasible that such stories of degenerate sessions are the result of anti-Egyptian and anti-Eastern propaganda, and that the reality was much healthier.

In the last four lines of $S .1 .8$, Priapus' loss of control of his bodily functions has a great surprise in store. The god lets off a fart which demonstrates the loss of control. Priapus' fart and the laughter not only symbolize Horace's contempt for witchcraft and witches, but also ridicule the witches and express his scorn for the many in Rome and Italy who keep their perpetrators in their profitable business.

Horace connects the events described in the poem with Cleopatra and Marc Antony by his choice for Priapus as narrator of the story and Canidia as the chief culprit. I interpret Priapus as a functional reference to Cleopatra and Marc Antony. Priapus, the mythical son of Dionysus and Aphrodite, played an important role in the cult of Dionysus in Hellenistic Egypt. Cleopatra had been introduced in Rome, when she joined Julius Caesar there in 46 B.C., as the queen of Egypt who was equal to Isis/Aphrodite. Antony let himself be applauded as the New Dionysus during his campaigns in Asia. When Antony ordered Cleopatra to meet him in Tarsus in 41 B.C. to discuss her contribution to the war effort, she made a magnificent entry on board of 
her ship as Aphrodite/Venus, the ancestress of the Julian house whose statue was still in the temple of Venus Genetrix in Rome. An archaeological discovery significant for my interpretation of S.1.8 was made in Pompeii when a Hellenistic statue was found of Venus leaning on a statuette of Priapus. Thus, the figure of Priapus in S.1.8 was easily recognized by the readers of the poem as referring to Antony and Cleopatra.

The meeting in Tarsus was the start of a twelve-year relationship that lasted until their deaths in 30 B.C. In the winter of 41 B.C. Cleopatra brought Antony to her palace in Alexandria, where Antony indulged with enthusiasm in Cleopatra's favours. Increasingly Cleopatra took over control of political affairs. According to Plutarch, the territories in the East stood opposed to those in the West, and he leaves no doubt that Cleopatra was the leader. Horace also alludes in Epod.17 to Eastern mythical sorcerers and sorceresses and to the festival of Thracian Cotytto at the Esquiline. Thus, in this sermo and in the last epodos, both written a few years before Actium, Horace writes about sorcery and alludes by means of Priapus to Cleopatra and Antony. Cleopatra held sway over Antony and many Romans through Eastern sorcery and magic. Horace shows in S.1.8 (and in Epod.17) that he considered sorcery and magic, that had penetrated Roman society more than was sound, to be dangerous for Rome. The connection with Cleopatra suggests the danger of all the dark Eastern forces which could demolish Roman values, not just by sorcery but also by possible military and political action by Cleopatra and Antony. In the event of a military action by the two, a substantial part of the Roman elite allied to the Egyptian queen and Antony would not be helpful. Added to this, at the time of writing of $S .1 .8$ black magic was also associated with the followers of Sextus Pompey.

Finally, Horace raises in S.1.7 and S.1.8, apart from specific issues in each poem, in both the same strategic issues. Specifically, in S.1.8, Horace calls attention to the dangers of sorcery and magic not only for the mental and physical health of those who take part in it, but also for the growing Eastern influence sapping the fortitude of Rome. It is likely that he therefore also supported the formation by Maecenas of a sort of police force who could deal with the witches' activities. The strategic issues referred to in both poems are the threat from Parthia and Egypt, and the alliance between Cleopatra and Marc Antony. Horace alludes in both to the latter's submission to Cleopatra. In S.1.7 he implicitly reproaches Antony with his mismanagement of his military and political responsibilities, and in S.1.8 he condemns Antony's compliance with Cleopatra's aspirations to create her own imperium in the East. Horace transmits in both the message to Maecenas that he supports the political agenda of Octavian, that is that Marc Antony ought to be removed, and that he takes Octavian's side in the struggle for power against Antony.

Horace returns in S.1.9 to the state of his relationships with Maecenas. The present poem has much in common with S.1.5. Both poems describe a journey, albeit that the one in S.1.5 from Rome to Brundisium is much longer than the stroll in Rome in S.1.9. The opening lines of the two poems are also similar. Further, both poems are concerned with meeting people, both strangers and friends. For example, in S.1.5 
the meeting with pompous local dignitary Aufidius Luscus is recorded, and that with vulgar Sarmentus, with both of whom Horace does not want to be associated in any way. This is very similar to Horace's response to the impertinent fellow who dominates the scene in S.1.9. In my view, the morning stroll and the confrontation with the fellow are examples of Horace's poetic fiction, like the events of S.1.5.

The poem opens with a description of one of the pleasures of life when one is released from burdensome and pitiable ambition. Horace has the opportunity to be more pleasantly occupied. Then, Horace is roughly roused by a man whom he only knows by name, who wants to engage Horace in his own plans. It turns out that the fellow's objective is to become an associate of Maecenas and that he wants Horace to arrange this. The ambitious fellow argues his case in a very vulgar and aggressive manner and thus demonstrates that he would not be a suitable candidate. In spite of Horace's efforts to shake off the man, the fellow takes the chance to display his poetic and artistic qualities. The pushy fellow could not have done worse as he mentions the wrong qualities and people, such as his speed of writing and his abilities as a dancer and singer which are superior to those of Hermogenes.

Reading the poem from the perspective of one of his credentials for Maecenas, it is likely that Horace designed the poem in such a way as to let the fellow, an outsider, describe the circle of Maecenas as a group that is nothing more than an ordinary collection of men, who spend their time dancing and singing and are interested in nothing else. This gave the persona Horace, who speaks in the first-person, the opportunity to communicate to Maecenas that he feels that he belongs to a very different circle: one of high intellectual and artistic repute with higher standards than those of similar circles or of those in a patron/client arrangement. Through the medium of the pushy fellow as the "speaker” Horace pays Maecenas two compliments. The first is his observation that Maecenas is a man of good judgment and uses this most skilfully in choosing his friends. The second compliment is his praise of the mutual relations within the circle where each member has his own place.

The fellow continues his harassment when he tries to draw Horace into his legal problems. This leads eventually to Horace's rescue when the fellow and he happen to meet Horace's friend Aristius Fuscus. Horace stops for a chat with Aristius and attempts to involve his friend in his predicament with the fellow, but his friend refuses. Thus, at this point in the mini drama, we have three actors who in different ways are concerned with membership of the circle of Maecenas. The first one is Horace, whose position we know: appreciating that he was admitted to the circle and content with his achievements so far. The second actor is the anonymous fellow who is keen to advance his career by being admitted, but whom Horace does not see as a suitable candidate. He is not and never will be one of them, although Horace does not explicitly states this. The poet gives us some indications with respect to the fictitious social position of the fellow, who praised particularly the quarters of the city and the whole of Rome, presumably referring to Octavian's refurbishing programme. If we look at the key characteristics of the fellow, namely his ambition, envy, and common 
behaviour, I suggest that the fellow is a nouveau riche businessman known for his very shady methods in his ventures. Although he showed himself off as a scholar, poet, and singer of sorts, I conjecture that it is more likely that he, in view of his appreciation of Octavian's building programme, symbolizes one of the many who got rich in real estate. The third actor is Aristius Fuscus, although in a very different role. He is not a member of Maecenas' circle. I conjecture that the reason why Aristius refuses to help Horace in his predicament with the pushy fellow is that Aristius symbolizes the position of the man who takes exception to the exclusive character of the group and thus does not want to be involved. A second option is that Aristius symbolizes the man who previously was refused membership.

Horace depicts himself in S.1.9 as a full member of Maecenas' circle expressing his appreciation of the way the circle is organised by Maecenas. The poem shows his pride at being recognised as somebody close to Maecenas, albeit by a pushy nouveau riche. He also feels perfectly capable to assess whether somebody fits as an associate. The pushy nouveau riche clearly does not meet the criteria. Without the help of Aristius he managed to get out of the predicament with the fellow. He is sure that Maecenas would go along with his judgement that such a man would not fit. Further, Horace makes the point that he has developed into an accomplished poet as he is saved from the nuisance of the fellow by Apollo, the god of poetry.

The final poem, S.1.10, has in most manuscripts an introduction of eight lines that was not written by Horace. If one accepts that the identifications of Cato (as Valerius Cato) and the grammaticorum equitum doctissimus (as Orbilius) are feasible, the unidentified author of the fragment conveys the following view. Lucilius' verses are faulty indeed and what Horace wrote in S.1.10 about those faults (of style) has the approval of the civilized commentator Cato, who is a far subtler adjudicator of the poets of old than for example Orbilius.

In S.1.10 proper Horace himself speaks again starting with a short résumé of S.1.4.113. Horace criticizes not only Lucilius' style of composing his verses in S.1.10.1-3 (like he did in S.1.4), but he also testifies in S.1.10.3-4 to the fact that he had praised earlier Lucilius for his satiric power. Horace reduces his praise of Lucilius in the following long passage, S.1.10.5-39. His line of argument is that if he were to condone a particular fault in Lucilius' poetry, he could just as well allow the same in any other poet's work. The key characteristic for his choice of any other poet is that the latter shows a fault which he also identified with Lucilius. His first target among past and recent poets is Decimus Laberius (106-43 B.C.), followed by Licinius Calvus (82-47 B.C.) and Catullus (84-54 B.C.), Pitholaus of Rhodes (first century B.C. - after 45 B.C.), and M. Furius Bibaculus of Cremona (born ab. 100 B.C., lived to a great age). He introduces two other features to his choice of the other poets. Firstly, all poets whom Horace censures in S.1.10.5-39 are known to have written lampoons against Julius Caesar, which suggests that Horace makes a political statement in favour of Julius Caesar and Octavian. In addition, he connects with his views on Lucilius' and the other poets' style his commentary on several other contemporary political issues. 
Horace also states in this passage his view on the attributes of good poetry. He sees as standards of good poetry sharply worded thoughts (brevitas) and variety of presentation (varietas). The poets of Old Comedy possessed those. This can be understood in a limited sense, namely that Horace sketches the stylistic qualities for satire, but it looks to me that Horace charts in those lines attributes which apply to several genres of poetry, in some of which he is already actively engaged. Horace also refers back to the opening lines of the fourth sermo (S.1.4.1-5) when he uses the same words (comoedia prisca viris) in both S.1.10.16 and in S.1.4.2. Thus, he reminds us in S.1.10 of a third quality in which the poets of Old Comedy set an example: censuring people and groups freely with libertas (freedom of speech).

His first target for criticism is Laberius, who wrote in an invective style, which Horace condemned in his and Lucilius' poetry. Next, Horace sneers at Hermogenes and an anonymous aper, who do not meet his standards. The identity of Hermogenes gave rise to much scholarly discussion; therefore, I discuss at this point the issue of the identity c.q. identities of Tigellius and Hermogenes in S.1. I conclude that the dead Tigellius of S.1.2 and S.1.3.4 is Marcus Tigellius Hermogenes, whom Porphyrio describes in his commentary on S.1.2.1-3, namely the musician of Julius Caesar's household. He died presumably in 40 or 39 B.C. The other man is the living Hermogenes of S.1.3.128-133, S.1.4, S.1.9 and S.1.10, who was also a Sardinian and who defected in 38 or 37 B.C. to Sextus Pompey. In order to differentiate clearly between the two, when I write Tigellius I refer to the dead man of S.1.2 and when I write Hermogenes I refer to the living man. The defection of Hermogenes to Sextus made him the target of Horace's criticism. The aper of Calvus and Catullus cannot be identified, but refers most likely to somebody whose knowledge of poetry does not go beyond the two poets. Both Calvus and Catullus wrote anti-Caesarian lampoons. Horace expresses a wish to keep his distance of the four men, because at least Calvus and Catullus had a history of disturbed relations with the Caesarian faction caused by their anti-Caesarian invectives in the past. Horace may have had still a second reason not to commit himself too much concerning Catullus, as it is likely that he knew of Maecenas' sympathy for Catullus' poetry.

Next, a long passage follows in lines 20-35 in which he speaks up for linguistic purity, condemning the mixing of Greek and Latin in both poetry and prose. Although good poetry relies to a high degree on variety, Horace criticizes Lucilius, who was in his opinion too unrestrained with his Grecisms. He makes a functional reference to the unknown Pitholeon, who should likely be identified with the wit M. Otacilius Pitholaus, who also lampooned Julius Caesar. Horace states tongue-in-cheek that it is no wonder that Pitholaus mixed Latin and Greek because he came for study to Rhodes. Horace felt very strongly about resisting the penetrating Greek cultural influence, and he felt that the Latin language and Roman culture needed to be protected. The guardian of Roman values, Quirinus himself, ordered him to write Latin verse. It is feasible that Horace - as in the case of Laberius, Calvus and Catullus - is also antipathetic of Pitholaus on grounds of his history of lampooning Julius Caesar. This 
is followed by a plea to preserve good standards of Latin in prose. Horace uses the example of the legal profession to make his case.

The last victim of Horace's criticism on past and recent poets and literary modes is turgidus Alpinus (the inflated man of the Alps). Porphyrio identifies turgidus Alpinus as M. Furius Bibaculus of Cremona. Horace did not rate his epic highly. He put it quite plainly that he condemned his style: his sarcastic turgidus (inflated, pompous) and iugulat Memnona (he murders Memnon). The latter qualification recalls S.1.4.59-62, when Horace raises the subject of metathesis and asserts that rearranging verses is like murdering the poet. Turgidus Alpinus rearranged perhaps an existing epic about Memnon and did not care that he created inadmissible changes to the meaning of the Memnon story. Furius Bibaculus also wrote invectives against both Caesars, which according to Tacitus were still read: "yet even the deified Julius himself and also the deified Augustus tolerated them and left them in peace." Contrary to the pompous Alpinus, Horace pretends in the next lines that he only writes trivial poetry for his own pleasure.

After his critical review of a number of past poets, Horace turns to his contemporary colleagues to begin with his friend Gaius Fundanius, a comic poet of the New Comedy, who also belonged to the circle of Maecenas. Horace suggests that Fundanius and he are partners in writing with a light touch. Next, he addresses C. Asinius Pollio (76 B.C. - A.D.4), a military man, consul in 40 B.C., and retired from politics soon afterwards. He was a convinced Republican and a supporter of Julius Caesar. Horace lauds Pollio as the living master of tragedy. The following in this line-up of famous poets is L. Varius Rufus (ab.70 - ab.15 B.C.), poet in the epic genre, who with Virgil introduced Horace to Maecenas and to whom Horace refers as one of his friends. His later tragedy Thyestes was enacted in 29 B.C. at the games after Actium. Virgil is then praised for his Eclogae, pastoral poetry with commentary on Octavian's land confiscations in Northern Italy after Philippi. Horace says about Virgil that "the Muses relishing the countryside have granted to Virgil tenderness and elegance.” Horace demonstrates his approval of Virgil's way of showing his compassion with the suffering smallholders by means of the very refined images and imaginative allusions in the Eclogae. After Virgil, it is the turn of P. Terentius Varro of Atax, who wrote an epic called Bellum Sequanicum about Julius Caesar's campaign against Ariovistus and two didactic poems, a geographical (Chorographia) and an agricultural (Epimenides). Only a few fragments of those works have survived. Whether he also wrote Satires is a vexed question: there are no extant satires. Although the testimonies by Propertius and Ovid lead me to the conclusion that Varro wrote elegiac rather than satiric poetry, S.1.10.46-49 suggests that Varro wrote indeed satires. As these appear to be completely lost, the question remains probably unresolved. Horace obviously did not rate Varro of Atax's achievements in satiric poetry highly. He makes a very important statement in S.1.10.46-49: he could do better in writing satire than Varro, although not as well as its inventor Lucilius. However, he does not presume to take the crown of satirical poetry from Lucilius. He does not want to be the inheritor of the inventor of satire, but 
he bows out of satiric poetry. If Horace was ever the leading satirist after Lucilius who set the new standards for the genre, particularly in S.1.4 and S.1.10, it is peculiar that he never wrote any satire, neither in $S .1$ and $S .2$ nor in any other work.

In connection with Horace's statement that he does not intend to be a writer of satire, it is useful to briefly summarize Horace's position with respect to his ideas about standards of good poetry. In my view, Horace does not define in S.1.10 his position with respect to satiric writing, but he defines his position with respect to style and content of his poetry in general. As he intends to write his future political commentary in different genres, he cannot afford to restrict his views on his poetic orientation to one genre only. I also noted in my discussion of S.1.3.29-34 that Horace considers in those lines his future style of delivering critical commentary in general. S.1.3.29-34 anticipated S.1.10.46-49 in which he says that he does not intend to become the successor to Lucilius.

Then, Horace works his previous criticism of Lucilius out further in the long passage that follows, S.1.10.50-71, and also places the criticism within the context of Lucilius' days. In addition, he finds some mitigations for Lucilius harsh style. He raises a new point, and the mere mention of the point shows that he tones down the criticism of Lucilius that he expressed in S.1.4. Horace looks more favourably on Lucilius when he goes deeply into the latter's poetry allowing for the political context of Lucilius' age. He asks whether Lucilius' lack of finish was caused by "his own nature or by the harshness of his subject matter?" I interpret the harshness of the subject matter as referring to the contemporary political situation when Lucilius wrote his satires. The question that Horace raises is whether the serious political issues of some hundred years ago and Lucilius' censure of those involved did not require an unpolished response: such reply was precisely what the malicious individuals of the past were deserving and what they understood. Horace recognized that the political context in which Lucilius worked was not all that dissimilar to that of his own age, that Lucilius' commentary on political and social issues was not dissimilar to his own ambition of becoming a political commentator, and that Lucilius kept his independence. In the final lines of this passage, S.1.10.64-71, Horace imagines how Lucilius would polish his style, if he were one of his contemporaries. Lucilius' personal qualities do not only meet Horace's standards, but he is also much more polished than expected. The traditional originators of new verse showed generally less refinement as they had not been immersed in the works of their Greek predecessors. Lucilius, however, was different. Lucilius is highly praised when Horace says that, if Lucilius were still alive, he could meet his standards of good poetry. Horace's opinion of Lucilius the literary man has developed in $S .1$ from one of rejection towards one of a fair degree of acceptance. Further, he expressed his respect for the political Lucilius. The acceptance of Lucilius was also a clever political statement towards the adversaries of Octavian, because it could at least reduce the power of the Republicans' claim that Horace attacked the value of freedom of speech, if not remove this claim altogether. 
In the final passage Horace gets very specific about the men with whom he wants to be associated. Wedged between a few poets he does not want to know, he presents a long list of colleague poets and some members of the political elite. The four men with whom he does not want to mix, Pantilius, Demetrius, Fannius and Hermogenes, have in common that they were all critical of Horace's poetry and of his political connection, although their criticism was presumably tinged with jealousy. The four are most certainly no candidates for admission to the circle of Maecenas. He is not impressed by their attacks as long as he sees that men like Fuscus, Plotius, Varius, Maecenas, Virgil, Pollio, Messalla and others like his verses. These men and many more whom he discreetly does not mention, are his fellow intellectuals and friends. They are literary men, scholars and orators, and men in high public office and patrons of the arts. It looks that he attained his end. Horace saved a final sneer for Demetrius and Hermogenes wishing them good luck with their trivial pursuits. Horace has done with them: they better "get lost."

The final line of S.1.10 and of the book "Go, boy, and quickly add these lines to my little book" refers to the whole poem reflecting Horace's relief that writing S.1 delivered the result: he had been admitted to Maecenas' circle and the book should be distributed amongst the circle as soon as possible.

I will present in the following section 3.3 Horace's political views as far as those become apparent from S.1. I will add to those a discussion of his political commentary in poems in the other genres he wrote simultaneously with $S .1$.

\subsection{The First Book of Sermones: Horace's Credentials and His Political Commentary}

I mentioned in the introduction to this chapter my hypothesis that Horace wrote the ten poems of $S .1$ as credentials for Maecenas in order to convince him that he would be a trustworthy associate after his improper affiliation with Brutus. Although Horace's main purpose writing the book is his self-presentation, he intertwines through his self-presentation his political commentary. Three subject-matters are relevant for the support of my conclusions. Firstly, Horace's reflections on his poetic orientation and his views on standards of good poetry: are those literary statements, or are those part of his efforts to win over Maecenas? I argue that his views on standards of good poetry are primarily part of his discussion with Maecenas about his political orientation. But, it is also clear, that those literary views are genuinely held by Horace and are well reasoned by him. Secondly, Horace reports in S.1 in several sermones about the progress of his efforts to become a member of Maecenas' circle and about his position within the group. I consider those statements important evidence in support of my hypothesis that $S .1$ is a collection of poems which were intended as material for a discussion with Maecenas about his worth as an associate. Thirdly, the political issues which Horace raises in $S .1$ can be interpreted within the context of his self- 
presentation on two levels, that is that he intends to demonstrate that he has views on contemporary political issues which are worth listening to and further that his opinions are in keeping with those of Maecenas and Octavian.

Firstly, Horace's reflections on his poetic orientation and his views on standards of good poetry are subject-matters supporting my hypothesis that $S .1$ is a compilation of his credentials. Horace's statements about style and characteristics of good poetry were primarily meant to convince Maecenas that he can write critical poetry in a manner which is acceptable to him. Horace chose a style of delivering his critical poetry that was inspired by his adherence to the Epicurean persuasion (S.1.3, S.1.4, and S.1.5), which also was the philosophical inspiration of Maecenas, and of a number of his poet friends, Plotius, Varius and Virgil. Horace's faithfulness to the Epicurean maxims for poetry as put into words by Philodemus of Gadara is apparent from his choice of the standards of good poetry, namely brevitas and libertas and his rejection of metathesis (S.1.4). The Epicurean maxims stem from their conviction that harmony, balance and unity are essential values. The maxims are in short the unity of ingenium and ars, res and verba, and the issue of the impossibility of metathesis: precepts which Horace's choice of standards reflects. Horace added in S.1.10 a third characteristic of good poetry, namely varietas. Thus, Horace's criticism of Lucilian satire is the result of his views on standards of good poetry: sharply worded thoughts and freedom of speech as taught by Philodemus, and variety. He does not reject the content of Lucilius' poetry, but his style (S.1.4 and S.1.10), although he toned down in S.1.10 his previous criticism of Lucilius' style in S.1.4 when he allowed for the political context of Lucilius' writing. In this way, he expressed his respect for the political Lucilius. The acceptance of Lucilius was also a clever political statement towards the adversaries of Octavian, reducing the power of the Republicans' claim that Horace attacked the value of freedom of speech.

Horace made already immediately after the opening of $S .1$ (S.1.1.15-22) an implicit statement about his moral guidance. He says that he is convinced that the people who feel wronged refuse to act according to either philosophical tenets or to the old veracities of the traditional Roman values. Those people are to blame for rejecting the old Roman values, as a return to those values might contribute to greater political and social stability. The old Roman values are one of the foundations of his outlook upon life in addition to his Epicurean persuasion. He returns to this theme (S.1.4 and S.1.6), but he also affirms ( $S .1 .5$ and $S .1 .6$ ) that holding the right traditional values does not mean that he is a naïve provincial bumpkin unfamiliar with the sophistication of Rome.

Horace, an unknown man from provincial Venusia, wants to demonstrate that he will be a reliable member of the circle of Maecenas. His reflections on style and content (S.1.1-1.4 and S.1.10) are not the result of his search for his poetic orientation, but are part of his discussion with Maecenas about his political orientation. For example, in the first four sermones he intertwines through his discussion of poetic style his views on the behaviour of several social classes in Rome, among others the 
aristocracy (S.1.2), the common people (S.1.4) and the new rich - the latter in all but one sermones. He wants to show to Maecenas firstly that he can identify the evils of specific sections of Roman society and secondly that he recognizes the groups with which he does not associate on grounds of - in Horace's view - their objectionable behaviour and improper political allegiance. And as a further example, Horace wants to show that his choice for the Epicurean persuasion is part of the right political choice against the Stoic belief generally held by the Pompeians and other adversaries of Octavian. He ridicules the Stoic paradox as absurd that leads to choosing the wrong men for public office (S.1.3). His views on style and content of good poetry do not imply that he intends to become a satirist (S.1.3 and S.1.10.46-49), but rather that he intends to write in several genres about, among other matters, political issues in a responsible manner acceptable to Maecenas and Octavian: a gentleman political commentator (S.1.3). Horace is also clear about what he does not want to achieve: he is grateful that he is not the son of one of the established families, that would have deemed him to pursue a career in politics (S.1.6). He does not say that he aspires for being an outsider in Roman politics, but he seeks to participate in his own way as a commentator.

The second subject is that of Horace's report in $S .1$ about the progress of his efforts to become accepted by Maecenas. He records at several places that he feels comfortable in the company of his friends. His first testimony is in S.1.3.139-140 where he writes about his own fortunate circumstances: his dear friends will forgive him if he makes a mistake. He felt accepted within a circle of real friends. This theme returns in S.1.5, where he voices his joy when meeting with his special friends Plotius, Varius and Virgil - all three members of the circle of Maecenas - during his fictitious journey to Brundisium. Horace expresses most clearly how much he holds his friends in affection in the final passage of S.1.10 when he praises his friends and fellow intellectuals within Maecenas' circle or those whom he met through his association with the latter. They are the literary men, scholars and orators, and men in high public office and patrons of the arts who like his verses. He closes $S .1$ with relief that writing the sermones delivered the result.

This feeling of being accepted goes together with giving expression to an increased confidence as a member of the circle. He writes in the third sermo rather unassertively about his friends, who will forgive him if he makes a mistake, but he is confident about his position within the group in the possibly fictitious seventh and ninth sermones. Although Horace still reports in S.1.6.56-57 that he felt embarrassed when he came into Maecenas' presence for the first time - possibly due to his previous association with Brutus' party - he writes in S.1.7 candidly about an experience in the company of Brutus, fictitious or not. From S.1.7 onwards, he sounds confident that he will succeed in his efforts to become an associate of Maecenas. In S.1.9 he behaves as a full-fledged member of Maecenas' circle expressing his appreciation of the way the circle is organised by Maecenas: one of high intellectual and artistic repute with standards higher than those in a patron/client arrangement. He is proud at being recognised as 
somebody close to Maecenas, albeit by a possibly imagined pushy nouveau riche. He also feels perfectly capable of assessing independently whether somebody fits as an associate. For a nouveau riche there is no place as a member of the circle.

His focus on his correct pedigree is another characteristic of Horace's efforts to make himself acceptable to Maecenas. He wants Maecenas to know that on grounds of his descent, education and personal development he is well qualified to become a worthwhile and reliable associate of Maecenas. He introduces this subject in S.1.4 after line 103 where he brings up his education and his outlook upon life. He recounts the role of "his father," which symbolizes the continuity of the old traditions with which he grew up. This is also apparent from S.1.5, where Horace pays special attention to Venusia and the quality of his upbringing in the provincial town again referring to his milieu symbolizing the continuity of the traditions. He grew up in a family having respect for the old Roman values. But, he also makes sure that he distances himself of provincial attitudes at three places in S.1.5. The theme of the continuity of the traditions and the symbolic role of "his father" returns in S.1.6, where he tells of his departure from Venusia and his good education in Rome. The right way of life and the right political ideas were handed down to him by the good Romans in his milieu in Venusia and by that of the social elite (eques atque senator) in Rome during his time with his teacher Orbilius.

The third subject, that of the political issues which Horace raises in S.1, can also be interpreted as part of his self-presentation. He intends to demonstrate to Maecenas that his views on contemporary political issues are worth listening to and further that his opinions are in keeping with those of Maecenas and of Octavian. I will summarize in this section his political convictions and I will also include those he discussed in his other work that he wrote in the period of 38 - 30 B.C., in Sermones book 2, the Epodi and some of the Carmina. I will explain below my reasons for extending the period to 30 B.C.

Horace's fundamental concern was the undecided political situation which resulted in regular changes of the balance of power leading to uncertain and fragile arrangements with respect to the administration of the state, and to the continuing struggle for power. He made a stand against the Republicans and Pompeians (S.1.1, S.1.3, S.1.6) and he took the side of Octavian in the conflict against Sextus Pompey and Marc Antony (S.1.2, S.1.7, S.1.8). The uncertainty encouraged many new men to make a push for gaining public office with the intent to further their own, financial, interests. The established political elite was much prejudiced against the new men, whom they saw as not qualified to carry out their duties properly. Only few supporters of Octavian could be found within the old aristocracy (S.1.6). Most of them supported Marc Antony, or even worse, Sextus Pompey. Because Octavian needed the support of the Senate which traditionally was dominated by the nobiles, Maecenas, and with him Horace, supported the claims of the old aristocracy that birth was an important qualification for high office. The new men were gaining much influence and became accepted by many of the social and political elite. They belonged often to the increasing number 
of freedmen (libertini) and their sons, or were military men. Horace was not opposed to social mobility (S.1.6), but he resented the new men who exhibited an unrelenting ambition for public office. He accepted that men who aspired for office should be judged on their individual merits.

Many new men also succeeded in becoming rich, of whom many used their wealth to attempt to buy political office. Horace condemned in every sermo of the first book - except in S.1.8 where he only briefly mentions a spendthrift nouveau riche, who finished up in the gutter - greed (avaritia), ambition (ambitio) and extravagance (luxuria), which he observes in all layers of society, from the common people (S.1.4) to the upper classes (S.1.2). He saw those vices as a threat to the traditional structure of Roman society. The number of new rich grew particularly amongst the negotiatores - the bankers, moneylenders, merchants and manufacturers in the provinces and in Italy - and amongst the military and the freedmen. Military men made their fortune in the areas where they settled after completing their time of service, or enriched themselves by the sale of booty they stole in the wars overseas or confiscated in the proscriptions (S.1.2). Others extracted as tax officials large amounts of money from local businessmen in the provinces (S.1.7). Horace condemned the lifestyle of the new rich, who showed their wealth in extravagant (particularly luxurious building) enterprises, not only in the Sermones, but also in a number of the Carmina. Horace relates the building of luxurious villas not only at the end of S.1.2 (section 2.2.1), but also in Carm.2.15 and Carm.2.18 (notes 289, 291).

In a number of places (S.1.2, S.1.4, S.1.7 and S.1.8) Horace expresses his opinion about the activities of Marc Antony or of Cleopatra and those of the two together. He was concerned about the conflict with Parthia, which Antony did not resolve (S.1.7), and the alliance between Cleopatra and Marc Antony (S.1.7, S.1.8) with the consequential strategic threat from both Parthia and Egypt. He implicitly reproached Antony with his mismanagement of his military and political responsibilities (S.1.7), and with his compliance with Cleopatra's aspirations to create her own imperium in the East. Horace saw the urgent necessity of strong leadership, and supported the political agenda of Octavian, that is that Marc Antony ought to be removed, and that he took Octavian's side in the struggle for power against Antony (S.1.8). He was not only apprehensive of the strategic and military danger coming from Egypt, but also of the cultural threat from the East. He attached much importance to the mos maiorum (S.1.1, S.1.4, S.1.6) and the Roman way of life and he saw Greek and Eastern cultural customs and practices which spread over many layers of Roman society as a danger for the preservation of Roman values. Horace was particularly worried about black magic denouncing the practices in several poems (S.1.8, Epod.3, Epod.5 and Epod.17). He voiced the generally felt concern caused by widespread sorcery despite the measures taken and connected the sorcery with Cleopatra, who was admired by a substantial part of the Roman elite. This would not be helpful in the event of a military action by Antony and the Egyptian queen. Added to this, Horace subscribed to the concern about witchcraft felt for reasons of local Roman policy. The leadership's unease was 
not only about the "traditional" black magic and the crime it attracted, but also about the resulting sexual debaucheries. Horace called attention to the dangers of sorcery and magic not only for the mental and physical health of those who take part in it, but also for the growing Eastern influence sapping the fortitude of Rome.

Horace also felt strongly that the Roman culture and Latin language needed to be protected, and that the penetrating Greek cultural influence should be resisted (S.1.10). He speaks up for linguistic purity condemning the mixing of Greek and Latin in both poetry and prose.

Horace gave his opinion upon freedom of speech (libertas) at several occasions (S.1.4 and S.1.10). He considered freedom of speech an important privilege for himself and all Roman free-born men seeing libertas as the consequence of one's responsibility to express one's opinion and not as the aspiration to interfere with the liberty of others. He made his statements about libertas at the time of great political changes in Rome, with the risk that the ruling classes discontinued the right of free speech. His assertion was a political stand against the Republicans and the Pompeians, who had adopted the position of being the defenders of free speech. Thus, Horace, the associate of Maecenas, and a follower of Philodemus and the Epicurean school, touched with a discussion of freedom of speech upon a very sensitive political issue.

When Horace wrote S.1, he also raised political issues in several other genres: the second book of Sermones (S.2), the Epodi (Epod.) and the Carmina (Carm.). In this section I will briefly examine his poems which contain political commentary in the three genres written in the period from 38 B.C. until 30 B.C. I have extended the period from 35 B.C. to 30 B.C. on the following grounds. We saw already that Horace wrote $S .1$ at a time of great political uncertainty. This changed in 30 B.C. when after Actium Octavian took Alexandria, and Cleopatra and Marc Antony died. I suppose that the political content in Horace's poems written during the period between 38 and 30 B.C. rests on the same political views as those which he held during his writing of S.1. My assumption is that the political context did not change sufficiently between 35 and 30 B.C. from that in the previous three years for Horace to change his views. In addition to Epod.3, Epod.5, Epod.17, Carm.2.15, and Carm.2.18, which I discussed above, I will consider the following poems which contain political commentary and were most likely written before 30 B.C.: S.2.1, 2.2, 2.3, 2.6, 2,7 and 2.8 (written between 35 and 30 B.C.), Epod.2, 4, 7, 8, 9, 12, 13 and 16 (written between 39 and 30 B.C.), and Carm. 1.7, 1.14, 1.35, 1.37 and 1.38 (written between 35 and 30 B.C.). ${ }^{342}$ Some of the poems of

342 For S.2, see Mayer (2005); Muecke (1993; 2007). For Epod., see Watson (2003). For Carm.1 and Carm.2, see Nisbet \& Hubbard (2001, 2004). I did not select Carm.1.15 for two reasons. The dating is uncertain and Nisbet \& Hubbard (2001, 188-191) make a convincing case that the carmen does not allude to Antony and Cleopatra, but that "rather, the genesis of the poem is a literary one, the desire to emulate the Greek lyricists in their rehandling of literary topics." For S.2, Epod., and Carm., see Seager (1993, 23 - 29). 
Carm.1 and Carm.2, the whole of Carm.3 and Carm.4, and the Epistulae were written after 30 B.C. ${ }^{343}$

Horace's concern about the never-ending civil war, the continuing struggle for power, and the Sicilian war against Sextus Pompey is apparent from Epod.7, 9, 13 and 16. In Epod.7, he criticizes Marc Antony, Sextus Pompey and Octavian for the ongoing war and power struggle. In Epod.9, Horace focuses on the battle at Actium; he is critical of Octavian's military qualities. He expresses in Epod.13 his sorrow that the war is still continuing and that some of his friends may not return. In Epod.16 he gives vent to his frustration at the renewal of the war suggesting abandoning Rome and Italy forever and go to rich isles to rebuild society with himself as a moral guide. ${ }^{344}$ If the dating of 34 B.C. for Carm.1.14 ("may calmer times arrive") is right, it is feasible that the poem expresses his disappointment about the situation after the defeat of Sextus Pompey, when he thought that there was hope of a better future. ${ }^{345}$ In Carm.1.35, probably written in 34 B.C. when Octavian planned an invasion of Britannia, Horace strongly denounces war: this time not only civil war, but also the outrage of war in foreign lands. There is a mood of pacifism, which suits the feeling of war fatigue, but not that of patriotism after Actium. Horace prays in the poem for the well-being of Octavian and his legions, who would be better employed against the Massagetae, a threat from the East that was so poorly handled by Antony (S.1.7). ${ }^{346}$ In Carm.1.7, Horace writes approvingly about Plancus, a senior statesman and general, who in 32-30 B.C. changed sides from the Antonian camp to that of Octavian. The carmen is a welcome to an important new ally showing to many that the fortunes of Antony and Cleopatra are collapsing. Horace's apprehension of Marc Antony's and Cleopatra's aspirations to create their own imperium in $S .1$ turns into relief after the death of the queen described in Carm.1.37 ("the Cleopatra Ode"). The poem demonstrates his concern about the threat during the whole decade of the thirties. In Carm.1.38, Horace condemns Oriental luxury, like he did in S.1, as he considered Eastern cultural customs and practices which spread over many layers of Roman society as a danger for the Roman values.

The issue of the new men who also succeeded in becoming new rich, which is very dominant in S.1, also returns in the other genres. Horace shows in S.2.6 the

343 For the dating of S.2 and Epod., see Nisbet (2007, 9-12), of Epod., see Watson (2003, 1-4), of Carm., see Nisbet \& Hubbard (2001, xxviii-xxx); Nisbet (2007, 12-14). For the dating of Carm.2.18, see note 290. For the dating of the books of Epistulae and Ars Poetica, see Bather \& Stocks (2016b, 3-4); Ferri (2007); Lowrie (2007, 85-86); Mayer (1994, 1-52); Nisbet (2007, 14-15).

344 For Epod. 7 and 16, conform Nisbet (2007, 9): “two impressive political poems, Epodes 7 and 16, expressing horror at the renewal of civil war. [...] Both epodes allude to the Parthian menace.”

345 For the dating of S.1.14 following the defeat of Sextus Pompey, see Nisbet \& Hubbard (2001, 180-181). Although some scholars consider the dating of Carm.1.14 as soon after Actium likely, Nisbet $(2007,13)$ states: S.1.14 "best suits the period before Actium."

346 For Carm.1.35, see Nisbet \& Hubbard (2001, 386-388). 
contrast between on the one hand the Epicurean view of living a satisfied life with little in the countryside and on the other the pursuit of unlimited profits, that he saw in the hustle of city-life. In S.2.8, where Maecenas is the guest of honour at a dinner party arranged by a nouveau riche, Horace shows that mixing the old elite and the new rich is a danger to a healthy society. Horace exposes in Epod.2 the cynical attitude of one of the representatives of the Roman nouveau riche, who above all are interested in the commercial possibilities of large scale farming and not at all in the traditional agriculture. ${ }^{347}$ The epodos mirrors the opening lines of S.1.4, in which he alludes to individuals in high office appropriating property, and carrying out other criminal action. It was the time of the expropriations and confiscations when the most fertile land was given to the veterans and of the structural changes in the agricultural sector, where the farming estates, the latifundia, were established at the cost of the traditional farmers with the help of capital of the new rich and the old elite. The expropriation of farmland after Philippi is also alluded to in S.2.2, where the Apulian farmer Ofellus lost his farm, but continued to work on his old property as a farmhand. Ofellus has succeeded in accepting his reduced circumstances without losing his independence of mind and is an example of good plain living as taught by the Epicureans. ${ }^{348}$ The new rich are also the subject of his message in Epod.4. A parvenu shows off his new wealth. The former slave was an officer in the navy of Sextus Pompey. The class of the new rich is not to be trusted as they do erode the old Roman values. Horace lays his trust in the members of the old established families to bring back order and justice. Epod.4 reminds us particularly of $S .1 .6$ with the discussion about social mobility, the political careers of freedmen or freedmen's sons, and the prejudices of the established political elite. ${ }^{349}$

Horace condemned in all but one sermones of $S .1$ extreme behaviour which he saw in the vices of greed (avaritia), ambition (ambitio) and extravagance (luxuria). He exposed those evils again in S.2.3 giving many examples, which he observed in all layers of Roman society. Horace, who expressed elsewhere his own ideas of finding a golden mean in behaviour (S.1.3), distanced himself from the rigid Stoic dogmas about the origin of the vices, namely that those are forms of madness. He refers to another Stoic dogma in S.2.7, that is that every fool is a slave implying that if both master and slave are ruled by their desires, they have no control over their own destiny and they are no different. The poet's answer, in addition to that of the golden mean in behaviour, is that control is the result of freedom. The discussion in S.2.7 also touches on his observation elsewhere that extreme behaviour is found in classes

347 For Epod.2, see Cipriani (1980); Watson (2003, 75-86). For S.2.6, see Muecke (1993, 193-196); For S.2.8, see Muecke (1993, 227-229).

348 For S.2.2 and S.2.3, see Mayer (2005, 154-155); For S.2.2, see Muecke (1993, 114-116). For S.2.3, see Muecke (1993, 130-131).

349 For Epod.4, see Watson (2003, 145-152). 
which are at the opposite ends of the societal scale, masters and slaves. The theme of extreme behaviour also emerges in Epod.8 and 12, where he criticizes the sexual moral, particularly of the cultured, sexually liberated women of the Roman elite. Horace may intend that his contemporary reader detects in the women of both Epodi either Cleopatra's domination of Antony, sexually and politically, or the (putative?) attempts of Fulvia to ensnare Octavian. There are no independent indications that those Epodi originated as a result of sexual approaches by Fulvia, which was suggested by Octavian's epigram of 41 B.C. at the time of the Perusian war. Thus, both Epodi can contain allusions to topical political issues. In Horace's view, Octavian was right to resist her - if the advances took place at all. ${ }^{350}$

The first sermo of book 2 has a political message concealed under the literary and legal discussion. Horace drew a respected lawyer, Trebatius, into the conversation and thus there could not be any doubt about the validity of his legal pronouncements. At the end Octavian is introduced to state that there is freedom to write or speak provided this is within the limits of good manners and this is not slander. In addition, Horace is positive about Lucilius in S.2.1. ${ }^{351}$ Horace gave his opinion of freedom of speech (libertas) in this poem, like he did in S.1.4 and S.1.10. His view expressed in S.2.1 was again a political stand against the Republicans and the Pompeians, who had adopted the position of being the defenders of free speech.

I also chose a few poems (S.2.5, S.2.6, Epod.1, Carm.1.17 and Carm.1.20), which belong to the category of poems describing his self-presentation and his efforts to make himself acceptable to Maecenas, but also contain political commentary although not often recognized. For example, Epod.1 (36 B.C. or 31 B.C.), which Horace places against the background of the preparations for a decisive naval battle, Naulochus or

350 For S.2.7, see Muecke (1993, 212-214). For Epod.8, see Watson (2003, 287-293). For Epod.12, see Watson (2003, 382-391). The possible allusion to Cleopatra acc. to Watson (2003, 293): "It is possible that the vetula [old woman of Epod.8] is the poet's sneering caricature of the type of well-born, cultured, sexually liberated woman who came to prominence in the late Republic; [...] (One suspects that Horace intended contemporary readers to detect in her disquieting resemblances to another dominating female, the Cleopatra of Epod.9.11-16.)." The epigram of six lines by Octavian against Fulvia was quoted by Martial in MART.11.20; this reads as follows: Caesaris Augusti lascivos, livide, versus/ sex lege, qui tristis verba Latina legis:/ "quod futuit Glaphyran Antonius, hanc mihi poenam/ Fulvia constituit, se quoque uti futuam./ Fulviam ego ut futuam? quid si me Manius oret/ pedicem, faciam? non puto, si sapiam./ 'aut futue, aut pugnemus' ait. quid quod mihi vita/ carior est ipsa mentula? signa canant!"/ absolvis lepidos nimirum, Auguste, libellos,/ qui scis Romana simplicitate loqui. (Malignant one, you who read Latin words with a sour face, read six wanton verses of Caesar Augustus: "Because Antony fucks Glaphyra, Fulvia determined to use the same punishment for me by making me fuck her in turn. I fuck Fulvia? What if Manius begged me to sodomize him, would I do it? I think not, if I were in my right mind. 'Either fuck me or let us fight,' she says. Ah, but my cock is dearer to me than life itself. Let the trumpets sound.” Augustus, you surely absolve my witty little books, knowing how to speak with Roman candor).

351 For S.2.1, see Muecke (1993, 99-101). 
Actium. He spells out his amicitia for Maecenas narrating his closeness to the major political events and his support for Maecenas. He remains independent as he does not expect any rewards for his support. In S.2.5, Horace explores the evil of inheritancehunting both as a reprehensible social circumstance resulting from a perversion of standards by greed and as an exploitation of genuine amicitia by a "friend." Horace condemns inheritance-hunting as a social threat because he sees this as a result of erosion of the old values. He rejects the exploitation of amicitia because he is gratified by his association with Maecenas which he sees as one of true amicitia. In Carm.1.17 (probably 33-31 B.C.), Horace describes the beauty and peace of his Sabine farm. He voices in the poem his happiness and gratitude having received the estate. Carm.1.20 (probably 31-30 B.C.) expresses Horace's pride and gratitude for becoming Maecenas' associate. The poem is about an invitation to Maecenas to come and drink wine which Horace had stored away on the day that Maecenas returned to public life after a dangerous illness. ${ }^{352}$ The two Carmina are reminiscent of S.1.5 and S.1.9, where Horace expressed his pride that he had been recognized as one of Maecenas' associates. Horace wants it to be known that he has become close to Maecenas. In S.2.6, he recognises the pleasures of living at the Sabine estate allowing him to enjoy the way of life he really likes. He also condemns however in this sermo the unlimited hunting of profits by the urban new rich.

In summary, we see that Horace addressed in Sermones book 2, Epodi and those Carmina which he wrote between 38 and 30 B.C. the same political issues as he did in Sermones book 1, and that he expressed the same opinions as in S.1.

\subsection{Virgil's Eclogae and Horace's Sermones Book 1 Compared}

In this section, I will compare Virgil's Eclogae with the first book of Sermones. Both books were written in broadly the same period: the Ecl. most likely between 42 B.C. and 35 B.C., S. 1 between 38 B.C. and 35 B.C. ${ }^{353}$ I conclude in Weeda (2015) that Virgil shows

352 For S.2.5, see Muecke (1993, 177-180). For S.2.6, see Muecke (1993, 193-196). I do not include Carm.2.13 and 2.17 which have a link with Carm.1.20. Horace describes in 2.13 his narrow escape from death as a falling tree on his Sabine estate lands on his head. Horace addresses Maecenas in 2.17 saying that their fates are linked. He expresses his gratitude that Maecenas has survived his serious illness (Carm.1.20) and he connects Maecenas' recovery to his own lucky escape from the falling tree (Carm.2.13). Acc. to Nisbet \& Hubbard (2004, 201) Carm.2.13 probably "belongs to 25 B.C.;” Nisbet \& Hubbard $(2004,272)$ do not give a dating for Carm. 2.17 other than stating that the ode was written some years before Carm.1.20. In my view, the datings of Carm.2.13 and 2.17 are too uncertain for the poems to be included in the period (38-30 B.C.) that I chose for examination.

353 The view of Virgil's Eclogae as pastoral poetry with political commentary is a recapitulation of Weeda (2015, 54-84, esp. 54-58 and 83-84) and of Weeda \& van der Poel (2016); see also note 4. For Virgil writing about political issues, see also Dominik (2009). For an extensive list of scholarly 
his concern with major contemporary political matters in each of the ten eclogae, which are true bucolic poems, presenting a pastoral world where nature and man can be in harmony and where poetry can possess healing power worth more than political power or status. But Virgil also showed other, more sinister aspects: his pastoral world was threatened or had already disappeared, not through mismanagement or indifference of the farmers, but through forces from outside. Seven eclogae which concern directly the expropriations are Ecl.1, 5, 6, 7, 8, 9 and 10. Virgil refers especially to the expropriations and the expulsions in the Mantua region in Ecl.1, 6, 9 and 10.354 Four poems contain a description of the indifference of and the exploitation by the new owners (in Ecl.5, 7, 8 and 9). In addition, the threat to the pastoral life (in Ecl.2, 3 and 9) and the destruction of rural communities (in Ecl.6, 8 and 9) are also described. He introduces in Ecl.4 his view of the preferred constitutional arrangements when the war is over, that is a hereditary form of non-elected political authority and one-man rule. Virgil wrote from his personal knowledge, referring not just to an unnamed general threat, land confiscations somewhere in Italy, but to very specific events in his own region, near Mantua. Presumably, he tapped into his own observations - and those of people he knew - of the land expropriations and its effects, using these for portraying the political and social state of affairs in Italy. In my view, Virgil did not express real personal experiences in the Eclogae, but used his personal knowledge and experience in order to expose the social and political situation caused by the decline of the rural order. Virgil did not describe historical events precisely, but adapted these using them as functional references. ${ }^{355}$ Bowersock $(1971,76)$ argues that "the scholia [Servius, Donatus and others] are worthless evidence for details of the land commission, and so is Virgil. That can only redound to the poet's credit. He has caught a mood, an atmosphere in his poems.” However, Virgil certainly introduced historical individuals. I suggest that Varus, Pollio and Gallus represent a special kind of historical allegories symbolizing the involvement of high-ranking officials without exactly specifying who was involved where. Thus, Virgil showed the gravity of the

literature about the Ecl., see Weeda (2015, 54 note 65). For the dating of the Ecl., see Weeda (2015, 60 note 76): "The year 42 is derived from the assumption that Ecl.2 and 3 were probably the earliest and were written before $E c l .9$, which was written in 41 or 40 B.C. The year 35 B.C. results from the reference to Octavian in Ecl.8.6-13. See also Clausen (2003,xxii-xxiii); Perutelli (1995, 28-31)." For the dating of the individual Eclogae, see Weeda (2015, 59-83). For the dating of Ecl.10, see Weeda \& van der Poel (2016, 9 note 17).

354 For example, Virgil refers to the expropriations in the Mantua region and the involvement of well-known men in Ecl.1, 6, 9 and 10. In particular, he mentions: Alfenus Varus (Ecl.6.6-12 and Ecl.9.26-29) and Gallus (Ecl.6.64 and Ecl.10.1-10, 22-23, 72-73) and indirectly even Octavian (Ecl.1.42-43). Conform Jenkyns (1998, 171): Virgil was "concerned for the distresses of his fellow countrymen, the Mantuans - so much is explicit - and to that extent personal experience enters into his allusions to the confiscations."

355 Scholars are divided w.r.t the question in which eclogae autobiography can be found. For an overview of the relevant scholarly literature, see Weeda (2015, 55-56 note 68$)$. 
situation. A number of passages can also be interpreted as referring to events affecting people who the poet knew well, such as Ecl.1 (Tityrus' attempt to extract a promise that his farm would not be confiscated in line 42), or Ecl.9.10 (Menalcas having won a reprieve for the family farm or other farms). There is also evidence, which has so far been neglected, that Virgil referred to the new reality of the social and economic relations in the countryside through his choice of names of personae. Examples are the impertinent Thyrsis, in Ecl.7.33-34, used to refer to new arrogant landowners, or Mopsus in Ecl.5 and 8 to refer to the new-comer soldiers, who replaced or exploited the traditional farming population. Further, the river Rhenus in Ecl.10 refers to the Reno (near Mantua), which Lycoris saw when she left Gallus, symbolising Gallus' loneliness as a result of the misfortunes of war. ${ }^{356}$

I dwelt intentionally upon the subject of Virgil's possible personal knowledge of and concern for the victims of the land confiscations as this may explain the nature of his political commentary in the Eclogae. Virgil was very concerned about the disappearance of farming and small holdings in Italy. In his poetry he voiced not only his concern and compassion with the suffering farmers, but he also pointed out political responsibilities. Virgil did not hold back in naming or in alluding to the men whom he held responsible. I read less praise of Octavian and his associates in the Eclogae than for example Nauta argues. ${ }^{357}$ Zetzel $(2006,50)$, in an essay about Horace's Sermones, writes that Virgil "does indeed deal with substantial problems and with the realities of Roman and Italian life in the Triumviral age.” However, I do not concur with his $(2006,50)$ conclusion that "it might be argued (as I [Zetzel] think Horace does argue), that to veil the moral and social issues under the mask of pastoral, to emphasize poetics rather than politics, to construct a smooth, elegant, and artificial world and diction [as Virgil does] is not the best way to write or to live in Rome of the mid-30s.” This is not supported by the results of my (Weeda, 2015, 54-84, esp. 84) study, in which I concluded that Virgil was critical of, among others, Octavian for their roles in the land expropriations in Ecl.1, 6, 7, 8 and 9. At the time of writing the Eclogae it was perhaps not the best time to show his criticism too openly. Virgil is an elegant poet indeed, who, through his allusions in virtually every ecloga, presents his critical political messages in a pastoral wrapping, thus subtly shrouding his viewpoint.

356 For Tityrus as a poetic persona, and not as representing Virgil, see Boucher (1966, 17). For Menalcas and a reprieve of farms in the Mantuan area in Ecl.9.7-10: Certe equidem audieram, qua se subducere colles/ incipiunt [...]/ omnia carminibus uestrum seruasse Menalcan (indeed I certainly heard that from where the hills begin to slope down gradually [...] your Menalcas saved them all with his songs). See also Weeda (2015, 73). For the river Rhenus in Ecl.10, see Weeda and van der Poel (2016). 357 Nauta (2006, 301-332) states that Octavian is praised in Ecl.1 (2006, 305-310) and in Ecl.8 (2006, 310-316), and “other nobles" (Pollio, Varus and Gallus) in Ecl.3, 6, 9 and 10 (2006, 310-316). See for my arguments, Weeda (2015, 59-83). 
According to Dominik (2009, 117-122), Virgil wrote not only about "green politics," such as "rural exploitation" $(2009,117)$, and the "destruction [of the landscape], often as the result of politico-military force and the shameless consumption of the civilized world" (2009, 119), but he also pointed out that "disintegration of the locus amoenus in the Eclogae is afforded political import not just by its manifest association to the intrusion of the urban superstructure, but especially by the personal tragedies of its inhabitants" (2009, 122). I argue that Virgil went further than that as he delivered political statements about the destruction of rural communities, originating in what he saw as the fundamental destruction of the way of life of the crofters and the substantial change, even loss of, traditional rural values.

So far, I have given in section 3.3 a comprehensive account of Horace's views on topical political issues as recorded in both $S .1$ and in other contemporary poems in several different genres, and I have given in the present section 3.4 a brief account of Virgil's in the Eclogae. I intend to compare the views of both poets in this final part of section 3.4 that is also the closure of the book. As it so happened that Horace expressed his opinion about Virgil's Eclogae in S.1.10.44-45, it is proper to begin with recalling the latter passage. ${ }^{358}$ Horace writes: molle atque facetum/Vergilio adnuerunt gaudentes rure Camenae (the Muses relishing the countryside have granted to Virgil tenderness and elegance). Horace praises Virgil's way of showing his compassion with the farmers after Octavian's land confiscations in Northern Italy after Philippi. Zetzel (2006, 45-52) explored the differences between Horace's Liber sermonum and Virgil's Liber bucolicon (Eclogae) within the literary frame pointing out not only the differences in style and the poetic tradition of both authors, but also the possibility of Horace responding in some poems of $S .1$ to Virgil's Eclogae. ${ }^{359}$ Yet, Zetzel (2006, 47) states also that "what is important about these writers [the models of Virgil and Horace] is not, at least in Horace's explanation, how they wrote, but what they wrote: poetry of substance, social criticism, philosophical speculation, moral commentary." I will look at "what Horace and Virgil wrote" about social, moral and political issues and intend to identify the differences.

Virgil focused in the Eclogae on the issues of the social and economic changes that took place in the rural communities of Italy which he saw in serious decline, and on the human suffering resulting from the never-ending civil war and the struggle for power between different factions. As he harboured great love for "old Italy," the land of farmers, Virgil was embittered and very concerned about the way the traditional

358 For the details of my reading of S.1.10.44-45, see the discussion of the relevant passage in S.1.10 in section 2.2.5, where I also explained my renderings of molle (tenderness) and facetum (elegance). 359 For the comparison of $S .1$ and Ecl., see also van Rooy (1973). I concur with Zetzel $(2006,46)$ that van Rooy's efforts to find parallels between each sermo and the corresponding ecloga are rather farfetched. Horace's objective writing S.1 differed so much from Virgil's objective writing Ecl. that one can hardly expect any convergence. 
social structures were being destroyed, and the way smallholders were being expelled from their farms. Virgil had personal knowledge of lawlessness, which he regarded as being a result of the long period of civil war, for which he held the leaders of the different factions responsible. Thus, we see that in the Eclogae he censures the poor conditions that befell the rural population caused by the expropriations, namely the threat to the rural communities and the indifference of and the exploitation by the new owners.

Horace, on the other hand, addressed in $S .1$ a much larger group of different political issues, in particular those relating to questions of international relations and military strategy, the management of the affairs of state, the rise of ambitious new men in high offices, general issues of moral values and behaviour of all layers of the Roman society, but especially of the new rich, and the threat from the East to Roman culture. We saw in section 3.3 several examples, which I will briefly recapitulate. Concerning the international affairs, Horace expressed at a number of places his opinion about the activities of Marc Antony and Cleopatra. He was concerned about Antony's lack of progress in the conflict with Parthia, and the alliance between Cleopatra and Marc Antony to create their own imperium in the East. Generally speaking, Horace was in the 30s B.C. much more critical of Cleopatra than Virgil was later in the Aeneis. On balance, Virgil's opinion of her was positive, particularly as appears from his modelling of Dido on Cleopatra and from the manner in which he portrayed Dido as queen being testament of his appreciation of Cleopatra's qualities. ${ }^{360}$ Horace saw the urgent necessity of strong leadership in Rome. With respect to the management of the public affairs and the new men who got involved, he made a stand against the Republicans and Pompeians and he took the side of Octavian in the conflict against Sextus Pompey and Marc Antony. He criticized the nouveau riche who tried to gain public office with the intent to further his own interests. He condemned the moral values of all layers of society in all but one sermones of the first book: greed (avaritia), ambition (ambitio) and extravagance (luxuria), which he observed in all layers of society, from the common people to the upper classes. He saw those vices as a threat to the traditional structure of Roman society. Another threat to Roman values and culture came also from the East. He attached much importance to the mos maiorum and the Roman way of life and he saw Greek and Eastern cultural customs and practices which spread over many layers of Roman society as a danger. Horace was particularly worried about black magic denouncing the practices in several poems.

Horace's approach to the political situation and the manner in which he expressed his opinions is that of the intellectual, while Virgil shows his sympathy for and consideration of his fellow human beings. This may be due to the different perspectives from which the two poets wrote. Virgil wrote the Eclogae from the

360 For a more comprehensive discussion of Virgil's opinion of Cleopatra, see Weeda (2015, 133-137; 146-148). 
perspective of denouncing the serious events in Northern Italy where the independent smallholders were turned into poor tenants, if not slaves. Horace, however, wrote $S .1$ from that of self-presentation making himself acceptable to Maecenas and indirectly to Octavian. He presented political views through which he could expect to find favour with Maecenas. Thus, Horace wrote about strategic and general political issues which were the subjects of attention for Maecenas and his associates. 